\title{
Reactive Oxygen Species \\ Act as Signaling Molecules \\ in Liver Carcinogenesis
}

\author{
María Cristina Carrillo, María de Luján Alvarez, Juan Pablo Parody, \\ Ariel Darío Quiroga and María Paula Ceballos
}

Additional information is available at the end of the chapter

http://dx.doi.org/10.5772/45966

\section{Introduction}

Reactive Oxygen Species (ROS) were viewed as the "bad" molecules of cells for a long time, but in the recent years, several lines of evidence indicate the contrary: ROS are essential participants in cell signaling and regulation depending on their concentration.

At present it is well established that ROS signaling is an important factor of many gene- and enzyme-catalyzed processes. ROS signaling is responsible for activation or inhibition of numerous processes catalyzed by protein kinases, phosphatases, and many other enzymes although these reactions proceed by heterolytic (non-free radical) mechanisms [1]. Therefore, ROS signaling can initiate both inhibition and activation of tumor formation. This fact might be of utmost importance for the development of anticancer treatment by the drugs possessing both prooxidant and antioxidant properties.

In this chapter, we summarize a series of experiments that have allowed us to establish the role of oxidative stress in the early development of liver cancer process and the effects of cytokines on the modulation of this process.

Through a series of in vivo and in vitro experiments we are able to describe:

- The oxidative stress status of a preneoplastic liver

- The modulating effect of Interferon $\alpha-2 b$ (IFN $\alpha-2 b)$ on this oxidative status that triggers the apoptotic mechanism in hepatic cells

- $\quad$ The role of TGF $\beta 1$ in the whole process

- The participation of FOXO transcription family proteins in the programmed cell death activated by IFN $\alpha-2 b$ and TGF $\beta 1$ 


\section{Experimental models of liver cancer development}

Hepatocellular carcinoma (HCC) is a malignant solid tumor that arises from the major cell type in the liver: the hepatocyte. HCC is the most common type of primary hepatic tumor; it represents approximately $6 \%$ of all malignancies and is the fifth most common tumor worldwide [2].

Nearly all types of primary liver tumors known to occur in humans can be reproduced by chemicals in laboratory animals, especially in rats [3]. In experimental carcinogenesis, preneoplastic foci of altered hepatocytes (AHF) emerge weeks or months before the appearance of hepatocellular adenomas and HCCs $[4,5]$ and this has also been discovered in human with hepatocellular neoplasms and/or cirrhosis [6]. This fact has led to the development of a number of in vivo systems for the study of early neoplasia in rat liver $[7,8]$. The initiation-promotion or two-stage model of cancer development mimics the early events of the latent period of human carcinogenesis. Several two stages models have been developed, including the protocols of Solt and Farber [9], Ito et al. [10] and Rao et al. [11], that comprise necrogenic doses of carcinogens or other models such as the protocols of Peraino et al. [12] and Pitot et al. [13] that use low, non toxic doses of carcinogens.

In this context, the initiation stage of cancer development can be produced in rat liver by the administration of diethylnitrosamine (DEN) [9-11], a complete carcinogen that produces DNA ethylation and mutagenesis [13]. Necrogenic doses of DEN cause massive hepatic necrosis followed by regeneration [14] and would be expected to cause not only increased gene expression related to regeneration, but also increased expression related to oncogene mutation. Administration of promoting agents causes selective enhancement of the proliferation of initiated cell populations over non-initiated cells in the target tissue [5].

Accordingly, we have developed a two-phase model of liver preneoplasia in rat: basically, the animals are initiated with two necrogenic doses of DEN and subsequently 2acetylaminofluorene (2-AAF) is administered as promoting agent. The experimental protocol takes six weeks, and at the end of the treatment animals show $5 \%$ of liver tissue occupied by microscopic preneoplastic foci. A diagram of the experimental model is shown in Figure 1.

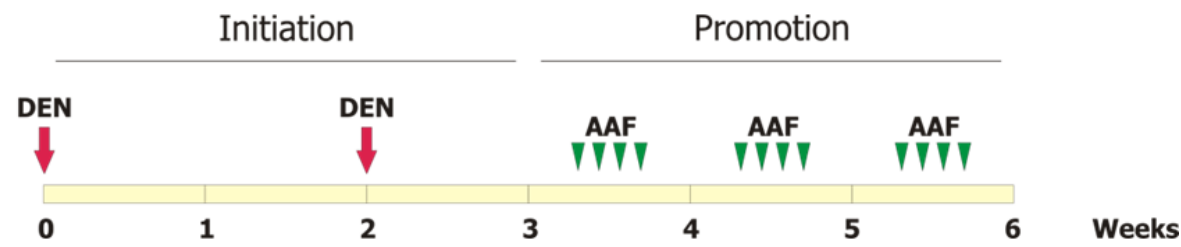

Figure 1. Two-phase or initiation-promotion (IP) model of rat chemical hepatocarcinogenesis. Initiation stage is performed by the administration of 2 necrogenic doses of diethylnitrosamine (DEN, $150 \mathrm{mg} / \mathrm{kg}$ body weight, intraperitoneal), separated by 2 weeks. A week after the last injection of DEN, the promotion phase begins by the administration of 2-acetylaminofluorene (2-AAF, $20 \mathrm{mg} / \mathrm{kg}$ body weight) by gavage, 4 days per week during 3 weeks. At the end of the sixth week, rat livers show microscopic preneoplastic foci. 
The presence of preneoplastic foci in this two-phase (initiation-promotion, IP) hepatocarcinogenic model was determined using rat Pi class isoenzyme of glutathione Stransferase (GST) as a foci marker [15]. This isoenzyme has been described as the most effective single marker of hepatic preneoplasia in the rat [16], and immunohistochemical detection of Pi class GST is the most widely used method for identification, quantitation and assessment of rat AHF [17].

\section{GSTs and liver preneoplasia: Our first studies}

GSTs are a family of multifunctional dimeric enzymes with an important role in detoxification processes of several xenobiotics, including anticancer drugs, carcinogens and mutagens [18-20]. These enzymes catalyze the nucleophilic attack of reduced glutathione (GSH) on electrophilic compounds [19,21].

Thus, GSTs are part of a cellular defense system which also includes GSH levels (and enzymes related to its biosynthesis) and proteins involved in the uptake of drugs and in the excretion of glutathione conjugates [22]. In the liver, among the several cytosolic classes of GSTs, Pi class GST (GST P), is particularly interesting because its expression in the adult tissue is associated with preneoplastic and neoplastic development [23]. In addition, increased expression of GST P was found to be associated with resistance of tumor tissues to several cytostatic drugs $[24,25]$.

There is a significative increase of GST P in preneoplastic livers. This enzyme has shown to be the more efficient isoenzyme in the catalysis of conjugation of ethacrynic acid (EA) with GSH. How does this enzyme act in the preneoplastic condition?

EA, an electrophilic loop diuretic drug, causes hepatotoxicity through lipid peroxidation mediated by its oxidative metabolism [26,27]. This drug has a preferential conjugation with GSH either spontaneous or GST catalyzed, reducing its intracellular levels and consequently favoring oxidative stress in isolated hepatocytes [27]. The glutathione conjugate of EA (EA$\mathrm{SG}$ ) is a substrate of human multidrug-resistance protein 2 (MRP2) and probably of rat Mrp2 [28]. Thus, it has been suggested that EA-SG is excreted through this active canalicular transport protein into bile [29]. In addition, EA and EA-SG (as well as many others $\alpha, \alpha$ unsaturated carbonyl derivatives and their glutathione conjugates) are important in vivo and in vitro inhibitors of several human and rat GSTs activities [19,30,31].

As was stated above, at the inactivation step, GSTs are playing a major role by catalyzing the conjugation reaction of GSH with the drug and leading to the inactivation of the therapeutic agent. EA and EA-SG have been proved to be good inhibitors of GSTs activities [19,30,31]. For this reason, we evaluated the enzymatic and cellular in vitro response to EA in isolated hepatocytes from preneoplastic rat livers, which present high levels of GST P, and analyzed the role of the GSTs/GSH system and Mrp2 (as a measure of the multidrug resistance) in these cells [15].

Results showed that hepatocytes from IP animals presented higher levels of cell viability than control hepatocytes in the presence of EA. In accordance with this data, IP hepatocytes 
showed lower levels of release of lactate dehydrogenase and alanine aminotransferase than control cells throughout the incubation time, indicating higher levels of cellular integrity. This suggests that hepatocytes from IP animals are more resistant to the cytotoxic effects of EA than control cells.

Control hepatocytes suspensions showed increased levels of lipid peroxidation measured through the quantification of TBARS (Thiobarbituric Acid Reactive Substances, [32]) production in a time- and dose-dependent manner in the presence of EA. This data was expected since oxidative metabolism of the drug and a subsequent lipid peroxidation was already described as part of the EA-induced toxicity [27]. However, IP hepatocytes suspensions did not show increased levels of lipid peroxidation during incubation at all times and EA-doses evaluated.

The higher basal levels of TBARS observed in preneoplastic hepatocytes could be attributed to the hepatocarcinogenic treatment, since it was described that lipid hydroperoxides are produced by some promotion regimens [33]. The unchanged levels during EA incubation are probably a consequence of both GST P activities: lipid peroxidase [34] and catalysis of EA conjugation with GSH, avoiding its oxidative metabolism.

Although intracellular total GSH (tGSH) levels decreased in both hepatocytes suspensions without EA, initial tGSH levels showed a mild although significantly higher value in hepatocytes from IP animals. This fact suggests that the small extra pool of tGSH is certainly an advantageous factor to prevent susceptibility to oxidative stress.

GST P has shown to be the more efficient isoenzyme in the catalysis of conjugation of EA with GSH $[35,36]$ and may have a role in the detoxification of lipid hydroperoxides through its selenium-independent peroxidase activity [34]. We observed decreased levels of both Alpha and Mu class GSTs in preneoplastic hepatocytes. This fact, and the presence of GST P in hepatocytes from IP rats, gives to this induced isoenzyme a compensatory role in these cells. Based on the measurement of total GST activity and in data obtained from other publications $[37,38]$, we have proposed that GST P could be playing a major role in the defense system against the cytotoxic effects of EA in our preneoplastic model. At high EA concentrations this resistance is overwhelmed over time, probably as a consequence of inhibition of GST P activity by EA-SG acummulation and depleted levels of intracellular tGSH. In the absence of GST P and GSH, EA may alkylate cell proteins thiols, which might be the major determinants of the cytotoxic effects observed with higher EA concentrations.

It has been demonstrated that MRP2 expression, the canalicular membrane protein reported to be the transporter of GSH and GSH conjugates, is higher in human HCCs than in normal cells [39]. MRP2 increased expression could suggest accelerated GSH depletion and hence, enhanced toxicity of cytotoxic compounds. On the other hand, diminution of MRP2 expression could indicate a preservation of GSH intracellular pool. In spite of the data demonstrated in human HCC, in our preneoplastic model, we observed a $75-85 \%$ decrease in the expression of Mrp2 in freshly isolated hepatocytes compared to control cells. Thus, for this reason, reduced levels of Mrp2 in preneoplastic liver cells could contribute to the 
preservation of intracellular GSH and would result, in addition, in an accumulation of EASG and a consequent inhibition of GSTs activities suppressing more GSH consumption.

We also saw increased levels of Mrp2 in intracellular microsomal membrane fraction in a EA-dose dependent manner in both control and IP hepatocytes. This internalization phenomenon was already described [40] and could imply a process which takes place as a feedback mechanism under GSH-consumption conditions at the highest dose of EA. Our results showed that the rate of internalization of Mrp2 with increasing doses of EA was markedly higher in IP hepatocytes, although the initial basal values were significantly lower. To our knowledge, this was the first study evaluating this accelerated internalization process in isolated hepatocytes from preneoplastic rat livers.

In conclusion, hepatocytes of IP rats showed an intrinsic resistance to the cytotoxic effects of low doses of EA and it seems likely that the presence of GST P, the higher levels of GSH, and the lower expression of Mrp2 in the cellular membrane are closely related to this phenotype.

\section{Interferon $\alpha-2 b$ gets into scene}

Human lymphoblastoid IFN $\alpha$ has been shown to have a powerful antiproliferative effect on human hepatoma cell line PLC/PRF/5 in a dose-dependent manner, both in vitro and in vivo, after implantation in nude mice. Moreover, IFN $\alpha$ inhibits liver regeneration by decreasing DNA and total protein synthesis [41,42].

Considerable expectations in reducing the incidence of HCC were connected with the use of IFN $\alpha$ in antiviral treatment of hepatitis B or C. By now, clinical trials have indeed confirmed a reduced incidence of HCC in IFN $\alpha$-treated patients with chronic hepatitis B or $C[43,44]$. In contrast, the benefit derived from IFN $\alpha$ treatment of established HCC remains controversial $[45,46]$. It is important to deepen the understanding of the action of IFN $\alpha$ on HCC cells, because some patients with hepatitis B- or hepatitis C-related liver diseases may already have small, clinically undetectable preneoplastic foci during IFN $\alpha$ therapy. Experimental studies have shown that IFN $\alpha$ exerts its antiproliferative effects against HCC cell lines in vitro by inducing apoptosis and inhibiting cell-cycle progression [47-49]. However, the sensitivity of early-stage HCC to IFN $\alpha$ could not be estimated from the sensitivity of the cell lines that have a larger number of gene abnormalities and higher proliferation capability, whereas the activity of IFN is expected to be minimal [50]. However, it was unknown whether IFN $\alpha$ prevents in vivo oncogenesis by expressing these effects in the very-early-stage, clinically undetectable cancer cells.

In this context, we have demonstrated that administration of IFN $\alpha$-2b during the development of rat liver preneoplasia significantly decreased both number and volume percentage of GST P-positive foci [14]. Particularly, these reductions where observed when IFN $\alpha-2 b$ was administered during the initiation phase or during the entire experimental protocol. However, when IFN $\alpha-2 b$ was administered during the promotion phase no effect on these parameters could be observed. Thus, the use of IFN $\alpha-2 b$ as an 
antitumor agent was lost when it was administered only at the 2-AAF phase. Nevertheless, we cannot discount that the lack of IFN $\alpha-2 b$ effect during the 2-AAF phase reflects some interaction between 2-AAF and the cytokine. Administration of IFN $\alpha-2 b$ during the initiation stage seems to be essential to exert inhibitory effects against DENinitiated hepatic carcinogenesis in the rat.

Contrary to our expectations, the proliferation index (measured by immunohistochemical detection of proliferating cell nuclear antigen or PCNA) in preneoplastic foci was not reduced by treatment with IFN $\alpha-2 \mathrm{~b}$. On the other hand, the apoptotic index (measured by TUNEL technique) in AHF was significantly increased in the groups that received IFN $\alpha-2 b$. The number of apoptotic cells and bodies in AHF after treatment with IFN $\alpha-2 \mathrm{~b}$ was higher than for control rats. Then, the reduction of both number and volume percentage of AHF in IFN $\alpha$-2b-treated animals is explained by a greater programmed cell death within the foci.

In regard to the effects of IFN $\alpha$ on the cell cycle progression of various normal and tumor cell lines, most studies have observed inhibitory effects on G1 to S phase transition [51,52]; other studies have shown $S$ phase accumulation in response to treatment with IFN $\alpha[48,49]$. In our studies, the animals with liver preneoplasia that were treated with IFN $\alpha-2 b$ showed a diminution in the percentage of preneoplastic hepatocytes in $S$ phase and an accumulation in the G1 phase. Although apoptosis may be initiated in any phase of the cell cycle, most cells undergo apoptosis primarily in the G1 phase of cycling cells, and there is a positive relationship between apoptosis and cell proliferation [53]. This relationship is explained by the presence of many cell cycle regulators/apoptosis inducers such as p53, which operates at the G1/S checkpoint [54].

In this connection, we examined whether p53 and 3 members of the Bcl-2 family (Bax, Bcl-2, and Bcl-xL), which are important regulators of apoptosis [53] were involved in IFN $\alpha-2 b-$ mediated programmed cell death. It is known that p53 down-regulates Bcl-2 [55] and upregulates Bax genes [56]. The role of the Bcl-2 family in IFN $\alpha$-induced apoptosis still remains controversial. For example, IFN $\alpha$-induced apoptosis in cells of hematopoietic and hepatic origins can occur without involvement of the Bcl-2 family [48,57] whereas transfection of IFN $\alpha$-sensitive cell lines with a Bcl-2 expression vector conferred partial resistance to cell death mediated by IFN $\alpha$ [58]. Our results showed that members of the Bcl2 family were involved in the apoptotic elimination of preneoplastic hepatocytes after treatment with IFN $\alpha-2 b$. Specifically, treatment with IFN $\alpha-2 b$ increased levels of the proapoptotic protein Bax, in parallel with increases of p53 protein levels. In addition, there were decreases in the levels of $\mathrm{Bcl}-2$ and $\mathrm{Bcl}-\mathrm{xL}$ proteins, which are known to promote cell survival through homodimerization. Bax protein promotes cell death via homodimerization, whereas heterodimerization with either Bcl-2 or Bcl-xL results in cell survival $[59,60]$. The relative prevalence of Bax and Bcl-xL protein are critical factors influencing cell fate, promoting either survival or death, whose ultimate outcome largely depends on the Bax/Bcl-xL ratio. Thus, apoptosis pathways can be activated under conditions in which Bax protein expression is elevated and/or Bcl-xL protein expression is decreased. 
We also observed increased Bax protein translocation into the mitochondria in the animals that received IFN $\alpha-2 b$. It has been established that subcellular localization of Bax protein is an important regulator of apoptosis. Bax is localized in the cytoplasm and translocates to the mitochondria at the early stage of apoptosis. Bax mediates its proapoptotic effects through a channel-forming activity of the mitochondrial membrane, resulting in disruption of mitochondrial function, release of cytochrome $c$, and apoptosis [61].

In brief, our experimental observations led us conclude that preneoplastic hepatocytes in the IFN $\alpha$-2b-treated rats are "primed" for apoptosis and undergo programmed cell death as a primary result of a substantial increase in the level of mitochondrial Bax protein, producing a further increase in the $\mathrm{Bax} / \mathrm{Bcl}-\mathrm{xL}$ protein ratio.

\section{Has TGF $\beta 1$ any role in this scenario?}

Given its antiproliferative, proapoptotic role in the liver, TGF $\beta 1$ could be expected to act as a tumor suppressor. However, various types of neoplastic liver cells respond quite differently to TGF $\beta 1$. Whereas some human and rat hepatoma cell lines are sensitive to TGF $\beta 1$ [62-64], resistance has been reported for other hepatoma cells [64,65]. In addition, TGF $\beta 1$ overexpression seems to be a hallmark of human liver cancer [66]. Thus, the relationship between TGF $\beta 1$ and cancer is complex: TGF $\beta 1$ may stimulate malignant progression itself; conversely, it can have tumor suppressor activity [67]. The escape of certain hepatoma cells from TGF 31 -induced apoptosis seems to be an important and essential step in malignant progression $[68,69]$. Moreover, it has been suggested that TGF $\beta 1$ overexpression is a late event in human hepatocarcinogenesis [66]. These data indicate that loss of TGF $\beta 1$ responsiveness is not an initiating or strongly predisposing event, but rather a late event in carcinogenesis $[67,70]$.

Therefore, it was of interest to study if liver preneoplasia as an early stage of cancer development is still sensitive toward TGF $\beta 1$ actions.

Given that the changes of pro- and anti-apoptotic proteins induced by IFN $\alpha-2 b$ in rats with liver preneoplasia were similar to those attributed to TGF $\beta 1$ in other experimental models $[62,63,71]$, we studied the possibility that TGF $\beta 1$ could be involved in the programmed cell death induced by IFN $\alpha-2 b$ [72]. Primary, we observed that serum TGF $\beta 1$ levels in the animals treated with IFN $\alpha-2 b$ were significantly increased. In accordance with this, immunohistochemical studies showed that IFN $\alpha-2 b$ treatment significantly augmented the quantity of TGF $\beta 1$-positive hepatocytes in preneoplastic livers. At first sight, these findings seemed to indicate that administration of IFN $\alpha$-2b increased serum TGF $\beta 1$ production and the number of TGF $\beta 1$-positive hepatocytes. Although the mechanisms by which IFN $\alpha-2 b$ treatment induced TGF $\beta 1$ in the preneoplastic livers were not completely explored, we observed, using Western blot analysis, that preneoplastic livers expressed higher levels of IFN $\alpha$ receptors than control livers. In addition, IFN $\alpha-2 b$ administration in animals subjected to the preneoplastic protocol induced elevated levels of phosphorylated Stat1, indicating activation of the IFN $\alpha$ pathway. 
Recent investigations have reported that the induction of apoptosis by endogenous TGF $\beta 1$ does not require an overall increase in its hepatic concentration [70]. In view of the fact that TGF $\beta 1$ hepatic content may not reflect the induction of apoptosis by this cytokine, we determined the nuclear content of $\mathrm{p}-\mathrm{Smads}-2 / 3$ (critical intracellular transducers of TGF $\beta 1$ signaling). We observed high levels of $\mathrm{p}$-Smads-2/3 proteins in the nuclear extracts of IFN $\alpha$ $2 \mathrm{~b}$-treated animals. These results corresponded with the increased number of TGF $\beta 1-$ positive hepatocytes, indicating increased TGF $\beta 1$ activation in rats with liver preneoplasia that received IFN $\alpha-2 b$.

Nonparenchymal cells, including Kupffer cells and peritoneal macrophages, are the main source of hepatic TGF $\beta 1$ [73,74]. Hepatocytes, however, may synthesize TGF $\beta 1$ in vitro [75] as well as during hepatocarcinogenesis [66]. During liver preneoplasia, neither peritoneal macrophages nor Kupffer cells secreted detectable levels of TGF $\beta 1$ when they were stimulated with IFN $\alpha-2 b$. Conversely, hepatocytes from normal, untreated livers did not secrete TGF $\beta 1$ in the absence or presence of IFN $\alpha-2 b$. Nevertheless, hepatocytes from preneoplastic livers produced and secreted detectable levels of TGF $\beta 1$ when they were cultured without IFN $\alpha-2 \mathrm{~b}$ stimulus, and IFN $\alpha-2 \mathrm{~b}$ presence in the culture media induced several-fold increases of TGF $\beta 1$ production.

In vitro studies with isolated hepatocytes have allowed us to demonstrate that IFN $\alpha-2 b$ induces apoptosis in hepatocytes from preneoplastic livers, measured by fluorescence microscopy and caspase-3 activity. These cells also had higher nuclear accumulation of pSmads-2/3, indicating increased TGF $\beta 1$ activation. When anti-TGF $\beta 1$ was added to the culture media, TGF $\beta 1$ activation and apoptosis induced by IFN $\alpha-2 b$ were completely blocked. Therefore, the apoptotic effect of IFN $\alpha-2 b$ is mediated by the production of TGF $\beta 1$ from hepatocytes.

Thus, our work determined for the first time that endogenous TGF $\beta 1$ is implicated in the increased apoptosis into the AHF of IFN $\alpha$-2b-treated rats. Taken together, these data clearly showed that TGF $\beta 1$, which is produced and secreted by hepatocytes from preneoplastic liver under IFN $\alpha-2 b$ treatment, stimulates hepatocytes apoptotic cell death in an autocrine/paracrine fashion. This postulated mode of action is in agreement with data published previously $[70,76,77]$. The reduction of preneoplastic foci by endogenous TGF $\beta 1$ early in the carcinogenesis process would likewise protect against tumor formation.

\section{Participation of ROS}

In a new series of in vitro experiments, we proved that IFN $\alpha-2 b$ induces the production of TGF $\beta 1$ in hepatocytes from preneoplastic livers by activation of NADPH oxidase complex (superoxide-producing enzyme consisting of membrane (gp91phox and p22phox) and cytosolic (p47phox, p67phox, and p40phox) components [78]), and TGF $\beta 1$ induces apoptosis through a mechanism linked to the production of ROS by the same oxidase [79]. In order to confirm that the induction of NADPH oxidase activity was the main pathway producing ROS, additional experiments were made using IFN $\alpha-2 b$ plus an inhibitor of NADPH oxidase activity, diphenyleneiodonium (DPI). Presence of DPI in the culture media totally 
blocked the activity of NADPH oxidase, the production of ROS and the subsequent apoptosis induced by IFN $\alpha-2 b$.

ROS production induced by IFN $\alpha-2 b$ showed a singular pattern of two peaks: one peak in ROS generation at 1 hour of culture, and another peak at 9 hours. The addition of antiTGF $\beta 1$ to the culture media did not block the production of the first peak of ROS whereas totally blocked the appearance of the second one. On the other hand, when ASC was added to the culture media the production of both peaks was abolished. Based on these findings, the postulated mechanism by which ROS act as signaling molecules in liver preneoplasia is as follow: IFN $\alpha-2 b$ induces, via NADPH oxidase activation, an early ROS production that serves as a messenger, promoting TGF $\beta 1$ production and secretion. This growth factor triggers the production of more reactive oxygen intermediates, as a late event, by inducing the same enzyme complex. It was demonstrated that synthesis of new protein is required for NADPH activation and subsequent apoptosis [80]. This event shows an additive response in ROS production and imposes the final onset of the apoptotic effect. The presence of ASC in the culture media totally blocked the increase in the activity of the NADPH oxidase complex, ROS production and the final apoptotic effect induced by IFN $\alpha-2 b$.

Once the source of ROS was assessed, we analyzed the cellular antioxidant defenses and their behavior during the studied times. We observed a reduction in tGSH levels from 7 hours of culture onwards. For that reason we studied if any form of glutathione was being exported out of the cell, and whether the biosynthetic GSH capacity was altered. We found an increase in oxidize glutathione (GSSG) levels probably due to the oxidation of the reduced form within the cytosol, and its exportation to the culture media, possibly in order to protect cells from a shift in the redox equilibrium. IFN $\alpha-2 b$ treatment resulted in the loss of GSH biosynthetic capacity since glutamate cysteine ligase (GCL) activity was decreased at 7 hours of culture and a rapid decrease of the mRNA expression of the catalytic subunit of GLC (GCLC) through a mechanism mediated by TGF $\beta 1$ was also observed. Moreover, it was found that IFN $\alpha$-2b-induced apoptosis in hepatocytes from rat preneoplastic livers is accompanied by the cleavage and loss of GCLC protein, through a mechanism mediated by TGF $\beta 1$.

A decrease in the antioxidant enzymes catalase (CAT) and superoxide dismutase (SOD) activities was observed when hepatocytes were treated with IFN $\alpha-2 b$. On the other hand, treatment with anti-TGF $\beta 1$ or ASC totally blocked the decrease in CAT and SOD enzymatic activities. These findings indicate that IFN $\alpha-2 b$ induced the decrease in enzymatic CAT and SOD activities by a mechanism mediated by ROS and TGF $\beta 1$. These enzymes probably protect hepatocytes from the initial IFN $\alpha$-2b-induced burst of ROS and this may be the reason for the rapid decrease of the first peak of ROS.

These results confirmed that the perturbation of the redox status produced by the IFN $\alpha-2 \mathrm{~b}$ induction of NADPH oxidase complex triggered TGF $\beta 1$ synthesis and secretion and assessed the downregulation of antioxidative systems. Similar data have been reported by Herrera et al. [80] when they treated fetal rat hepatocytes with TGF $\beta 1$. 
Since ASC abolished all the apoptotic effects induced in vitro by IFN $\alpha-2 b$, we determined the relevance of ROS on the onset of the apoptotic process in vivo, in the whole preneoplastic liver. IFN $\alpha$-2b plus ASC treatment of rats with liver preneoplasia abrogated the apoptotic effect induced by IFN $\alpha-2 b$, leading to no reduction on size/number of foci. Interestingly, foci volume was almost twice higher in the animals that received IFN $\alpha-2 b$ plus ASC than in IFN $\alpha$-2b-treated rats. This result highlights the importance of ROS signaling during the beneficial effects of IFN $\alpha-2 b$ treatment of hepatic preneoplasia. In this regard, it was found that ASC at low concentrations stimulates growth of malignant cells [81], while inhibits their growth at high doses [82]. At the present time, many cancer patients combine some forms of complementary and alternative medicine therapies with their conventional therapies. The most common choice of these therapies is the use of antioxidants such as vitamin C. It must be assumed that any antioxidant, used to reduce toxicity of tumor therapy on healthy tissue, has the potential to decrease effectiveness of cancer therapy on malignant cells [83]. Some data suggest that antioxidants can ameliorate toxic side effects of therapy without affecting treatment efficacy, whereas other data suggest that antioxidants interfere with radiotherapy or chemotherapy [83].

In summary, we demonstrated that increase in ROS levels turns on the process of programmed hepatocytes death, leading to the elimination of these malignant cells. The inhibition of ROS production with an antioxidant such as ASC in the co-treatment with IFN $\alpha-2 b$ may be not a beneficial therapy for the prevention of preneoplastic foci.

\section{Is p38 MAPK implied in the process?}

p38 MAPK pathway has been implicated in a wide range of cellular functions. However, it is now well established that p38 MAPK activation and its role depends on the cellular context, on the specific stimuli, and on the specific p38 MAPK activated isoform [84]. There are controversies about the role of p38 MAPK in apoptosis. It has been shown that p38 MAPK signaling promotes cell death $[85,86]$, whereas it has also been shown that p38 MAPK cascades enhance survival $[87,88]$, cell growth [89], and differentiation [90]. Furthermore, it has been reported that p38 MAPK participates on the estradiol-mediated inhibition of apoptosis in endothelial cells [91], while participates on the apoptosis induced by thrombospondin-1 [92], or by high leves of D-glucose in the same cells [93]. It is believed that p38 MAPK mediates its apoptotic effects through the phosphorylation of proteins of the apoptotic pathways [94].

Previous reports in hematopoietic cells have shown that IFN $\alpha$ and TGF $\beta 1$ play their growth inhibitory effects through activation of the p38 MAPK pathway via phosphorylation (activated p38 MAPK or p-p38 MAPK) [95]. However, these effects are primarily ascribed to G1 cell cycle arrest and not to induction of apoptosis. Others have suggested that during the TGF $\beta 1$-induced apoptosis in fetal rat hepatocytes, ROS activates p38 MAPK not by induction of apoptosis, but mediating ROS regulation of TGF $\beta 1$-gene expression [96]. On the other hand, it was demonstrated that inactivation of p38 MAPK pathway in cultured mice fibroblasts promotes tumor development [97]. Moreover, it was demonstrated that treatment with an inhibitor of p38 MAPK activation, induced carcinogenesis in mice resistant to tumor development, indicating the leading role of p38 MAPK in the regulation of tumor growth [98]. 
Using in vivo studies we could demonstrate that rats subjected to a 2-phase model of chemical hepatocarcinogenesis have less hepatic p38 MAPK activation than control rats, determined as p-p38 MAPK levels [79]. This is in agreement with Honmo et al. [99] that showed that 2-AAF administration induces a decrement of p38 MAPK activation promoting tumor development.

Another important finding of the in vivo studies was the effect of IFN $\alpha-2 b$ on the activation of p38 MAPK in rat preneoplastic livers. Preneoplastic animals treated with IFN $\alpha-2 b$ showed similar p-p38 MAPK levels to those in controls. In this connection, cultured hepatocytes from preneoplastic livers treated with IFN $\alpha-2 b$ plus SB-203580 (inhibitor of $\alpha$ and $\beta$ isoforms of p38 MAPK), totally blocked the IFN $\alpha-2 b$-induced apoptosis. It is clear that activation of p38 MAPK pathway plays a key role in promoting apoptosis after IFN $\alpha$ $2 \mathrm{~b}$ treatment in our model of experimental preneoplasia. It was previously reported that IFN $\alpha$ suppresses the growth of leukemia cell progenitors through activation of p38 MAPK, which leads to cell cycle arrest in different phases [100].

We demonstrated that IFN $\alpha-2 b$ induces an early production of ROS (first peak), in hepatocytes from preneoplastic livers. Then, ROS stimulate the production and secretion of TGF $\beta 1$ from hepatocytes, which in turn, generates a new burst of ROS (second peak). These oxygen radicals act as signaling mediators of the onset of the IFN $\alpha$-2b-induced apoptosis.

Activation of p38 MAPK after IFN $\alpha$-2b stimulus occurred preceding each increment in ROS generation and so, the particular pattern of two peaks was also functioning for p38 MAPK activation. Interestingly, treatment with ASC was able to block only the second peak, indicating that early activation of the pathway was independent of ROS, while late activation depended on ROS produced by endogenous TGF- $\beta 1$. Treatment with anti-TGF $\beta 1$ completely blocked the second p38 MAPK, demonstrating that TGF $\beta 1$ induces activation of p38 MAPK through ROS, as previously reported in fetal rat hepatocytes [96].

Another relevant issue is the activation of transcription factors by p38 MAPK. Cell signaling pathway activation could be transmitted to the nucleus in different ways, depending on the stimulus. To assess whether activation of p38 MAPK transmitted the IFN $\alpha$-2b stimulus to the nucleus, we analysed phosphorylation status of specific p38 MAPK transcription factors CREB/ATF-1 and ATF-2. Our findings documented that early p38 MAPK activation under IFN $\alpha-2 \mathrm{~b}$ stimulus mainly activates the transcription of ATF-2-regulated genes, whereas the late signal of p38 MAPK activation is transmitted to the nucleus mainly by the phosphorylation of CREB/ATF-1. Moreover, it can be also inferred that early phosphorylation of ATF-2 may be dependent on activation of p38 MAPK by IFN $\alpha-2 b$, while late phosphorylation of CREB/ATF1 may be dependent on activation of p38 MAPK by TGF $\beta 1$.

\section{Relationship between $\mathrm{p} 38$ and NADPH oxidase}

We inferred that p38 MAPK activation is essential for NADPH oxidase to function in preneoplastic hepatocytes treated with IFN $\alpha-2 b$, because the presence of p38 MAPK inhibitor SB-203580 totally blocked the activation of the enzyme [101]. Cytosolic component of NADPH oxidase complex, p47phox got phosphorylated following the same pattern as 
p38 MAPK induction and ROS generation: an early, first increment and a late, second increase. The first increase of p47phox phosphorylation by IFN $\alpha-2 b$ was independent of ROS, since ASC did not block such phosphorylation. However, it was dependent of p38 MAPK activation, since it was blocked by SB203580. This is a very interesting finding since it suggests that p-p38 MAPK phosphorylates p47phox, initiating the activation of NADPH oxidase in cells from preneoplastic livers. Analysis at higher times demonstrated that late phosphorylation of p47phox was completely blocked by anti-TGF $\beta 1$ or ASC, evidencing the participation of TGF $\beta 1$ and ROS in this process. Studies of $\mathrm{p} 47 \mathrm{phox}$ translocation from cytosol to plasma membrane were consistent with the phosphorylation findings.

It is clear that in liver preneoplasia there is a positive cross-talk between IFN $\alpha-2 b$, TGF $\beta 1$ and p38 MAPK pathways. Taken altogether, evidence indicates that p38 MAPK pathway plays a critical role in the generation of the suppressive effects of IFN $\alpha-2 b$, as well as TGF $\beta 1$ in the very early stages of hepatic neoplasia. There is strong indication that this signaling cascade acts as a converging signaling point for signaling pathways activated by different cytokines to mediate apoptotic or suppressive signals. These findings may have important clinical implications, as improving the pharmacological development of better drugs for the prevention and treatment of hepatic illness such as cancer.

\section{How are IFN $\alpha$ and TGF $\beta 1$ signaling pathways connected?}

Interactions between TGF $\beta$ and other cytokines signaling pathways have been extensively studied, particularly the cross-talk between TGF $\beta /$ Smad and IFN $\gamma /$ Stat signaling in their antagonistic role on collagen deposition and fibrosis [102-107]. However, despite the fact that TGF $\beta$ plays a crucial role in cancer, little is known about TGF $\beta$ signaling interactions during this process. An investigation in hepatoma cells have described a cross-talk between Il- 6 and TGF $\beta$ signaling [108] and another study in a melanoma cell line normally resistant to IFN $\alpha$, have demonstrated that co-stimulation with IFN $\alpha$ and TGF $\beta$ induces antiproliferative activity [109].

As was stated above, the relationship between TGF $\beta$ and cancer is complex: it functions as a tumor suppressor in early epithelial carcinogenesis, but often becomes prooncogenic in late stages of tumor progression [110]. Autocrine TGF $\beta 1$ is known to suppress tumorigenesis and tumor progression in normal and early transformed cells, but it can also promote the survival of various cancer cells [111]. Besides, dysregulation of the downstream effectors of TGF $\beta$ has been described in late steps of promotion stage, indicating that may contribute to the progression of preneoplastic lesions [112].

We demonstrated that during liver preneoplasia TGF $\beta 1$ has a beneficial role, promoting apoptotic death of AHF. Therefore, we attempted to get more insight into the relationship between IFN $\alpha-2 b$ and autocrine TGF $\beta 1$ in preneoplastic rat livers. Many in vitro cell systems are good tools to explain related actions of distinct types of cytokines in various biological signaling pathways, but they are not physiological. However, the study of IFN $\alpha$ $2 \mathrm{~b}$ and TGF $\beta 1$ signals interactions in hepatocytes derived from the whole preneoplastic liver may be relevant for understanding the mechanisms operating in patients with chronic 
hepatitis B or C treated with IFN $\alpha-2 b$, who already have small, clinically undetectable preneoplastic liver foci during therapy.

The obtained results provided evidence for the integration of TGF $\beta 1$ and IFN $\alpha$-2b signaling pathways during the development of liver carcinogenesis. IFN $\alpha-2 b$ treatment of hepatocytes from preneoplastic livers produced a rapid activation of IFN $\alpha$ signaling, with increased p-Stat1 levels. Subsequently, autocrine TGF $\beta 1$ produced under IFN $\alpha-2 b$ stimulus was able to induce the activation of TGF $\beta 1 /$ Smad signaling pathway, determined by nuclear content of $\mathrm{p}-\mathrm{Smad} 2 / 3$ and confirmed by the use of specific TGF $\beta 1$ signaling inhibitors (antiTGF $\beta 1$ and SB-431542) [113].

A critical mechanism for regulating the cellular response to cytokines resides at the level of receptor expression. TGF $\beta$ RII plays a key role in receptor activation and subsequent TGF $\beta 1$ signal propagation, functioning both to bind ligand and to activate TGF $\beta$ RI. Disorders of TGF $\beta$ RII expression lead to various diseases. For example, reduction of TGF $\beta$ RII levels contributes to the resistance of tumor cells to TGF $\beta$ [114].

We observed that TGF $\beta$ RII was up-regulated at mRNA and protein levels. This induction was mediated by autocrine TGF $\beta 1$, since it was blocked by inhibitors of TGF $\beta 1$ signaling. This is an outstanding finding, since TGF $\beta 1$-dependent regulation of TGF $\beta$ RII has not been previously reported.

Inhibitory Smad7 is a key component of TGF $\beta 1$ signals. Its expression is not only induced by TGF $\beta$, but also controlled by, for example, IFN $\gamma[102,107]$. Therefore, Smad7 is considered as a protein involved in the fine-tuning of the cellular responses to the TGF $\beta$ family by integrating various signaling pathways. However, in our model, Smad7 did not show changes in its protein levels, at least during the studied times. Furthermore, Smad7 protein levels in hepatocytes from preneoplastic livers were significantly reduced with respect to their levels in hepatocytes from normal livers. So, additional experiments of Smad7 induction by phorbol 12-myristate 13-acetate (PMA) were performed in order to evaluate if the decreased Smad7 levels showed in preneoplastic livers may contribute in TGF $\beta 1$ signaling activation. Results showed that this possibility seems unlikely; provided that Smad7 protein reached similar levels to those in normal hepatocytes, and TGF $\beta 1$ signaling continued activated. These experiments indicated that Smad7 protein is not directly related with TGF $\beta 1$ and IFN $\alpha$ signals interaction in hepatocytes from preneoplastic livers.

Another decisive aspect in signaling pathways relationships is the availability of certain coactivators for interacting with specific transcription factors. The cofactor p300 is an important component of the transcriptional machinery that integrates TGF $\beta /$ IFN $\gamma$-induced signals [115].

In normal fibroblasts exposed to IFN $\gamma$ and TGF $\beta$ simultaneously, activated Stat1 and activated Smad2/3 compete each other for limiting p300. IFN $\gamma$-activated Stat 1 appears to sequester $\mathrm{p} 300$, thereby disrupting TGF $\beta$-induced interaction of $\mathrm{p} 300$ with Smad2/3. Ectopic p300 rescues stimulation in the presence of IFN $\gamma$, suggesting that p300 acts as an integrator of IFN $\gamma /$ Stat1 and TGF $\beta / \operatorname{Smad} 2 / 3$ signals [103]. In addition, Inagaki et al. [116] have demonstrated that IFN $\alpha$ antagonizes TGF $\beta /$ Smad-induced hepatic fibrosis by competition between Stat1 and Smad3 for binding to p300 protein. 
In our study, we found that IFN $\alpha-2 b$ induced a direct interaction between activated Stat1 and p300 in hepatocytes from preneoplastic livers. Furthermore, activated Smad2/3 induced by autocrine TGF $\beta 1$ were able to physically associate with p300. In addition, levels of p300 in hepatocytes from preneoplastic livers were significantly higher than in normal hepatocytes. Together, these findings suggested that in hepatocytes from preneoplastic livers, the intracellular signals triggered by TGF $\beta 1$ and IFN $\alpha-2 b$ are integrated at the nuclear level, where p-Stat 1 and $\mathrm{p}-\mathrm{Smad} 2 / 3$ are capable of interact with p300, present in no restrictive cellular amounts.

It was recently found that TGF $\beta$ signals potentiate Il-6 signaling in hepatoma cells. This cross-talk occurs by physical interactions between Stat3 and Smad3, bridged by p300 [108]. In our model of liver preneoplasia we did not observe physical interaction between Stat1 and Smad3, but it seems to be enough p300 protein available to interact with p-Stat1 on one hand, and with $\mathrm{p}-\mathrm{Smad} 2 / 3$ on the other, leading to the activation of TGF $\beta 1$ and IFN $\alpha$ signaling simultaneously.

In fact, we have described for the first time a positive cross-talk between IFN $\alpha$ and TGF $\beta 1$ signaling.

\section{Summary \# 1}

In these series of experiments, it was demonstrated that NADPH oxidase complex is activated when IFN $\alpha-2 b$ binds to type I receptor. This binding produces early amounts of ROS. ROS, in turn, trigger TGF $\beta 1$ production and secretion. TGF $\beta 1$, when binding to its receptor, also induces NADPH oxidase complex activation, and, besides, decreases the antioxidant defenses of the cell. Moreover, we demonstrated that p38 MAPK activation is essential for NADPH oxidase to function.

Furthermore, ROS initiate mitochondrial apoptosis directly and/or acting by the Bcl-2 family proteins inducing a mitochondrial permeability transition pore (MPTP), releasing cytochrome $\mathrm{c}$ and activating caspase 3 . TGF $\beta 1$ could induce, as a late event, the activation of caspase 8 , which, in turn, induces a higher MPTP through activation of Bid, another Bcl-2 family member [117]. A graphic outline of these concerns is shown in Figure 2.

Altogether, our results demonstrate that the oxidative stress induced in preneoplastic liver by IFN $\alpha-2 \mathrm{~b}$ is able to trigger the apoptotic mechanism and brings into the play another key cytokine in the cancer process: TGF $\beta 1$.

\section{Targeting the $\mathrm{Wnt} / \beta$-catenin signaling pathway}

Among the growth factor signaling cascades dysregulated in HCC, evidences suggest that the Wnt/Frizzled-mediated signaling pathway plays a key role in hepatic carcinogenesis. Aberrant activation of the signaling in HCC is mostly due to dysregulated expression of the $\mathrm{Wnt} / \beta$-catenin signaling components. This leads to the activation of the $\beta$-catenin/TCF dependent target genes, which control cell proliferation, cell cycle, apoptosis or motility. It has been shown that disruption of the $W n t / \beta$-catenin signaling cascade displayed anticancer properties in HCC [118]. 
For this reason, we determined the status of the Wnt $/ \beta$-catenin/TCF pathway in the preneoplastic stage and evaluated the possible effects of IFN $\alpha-2 b$ on this pathway.

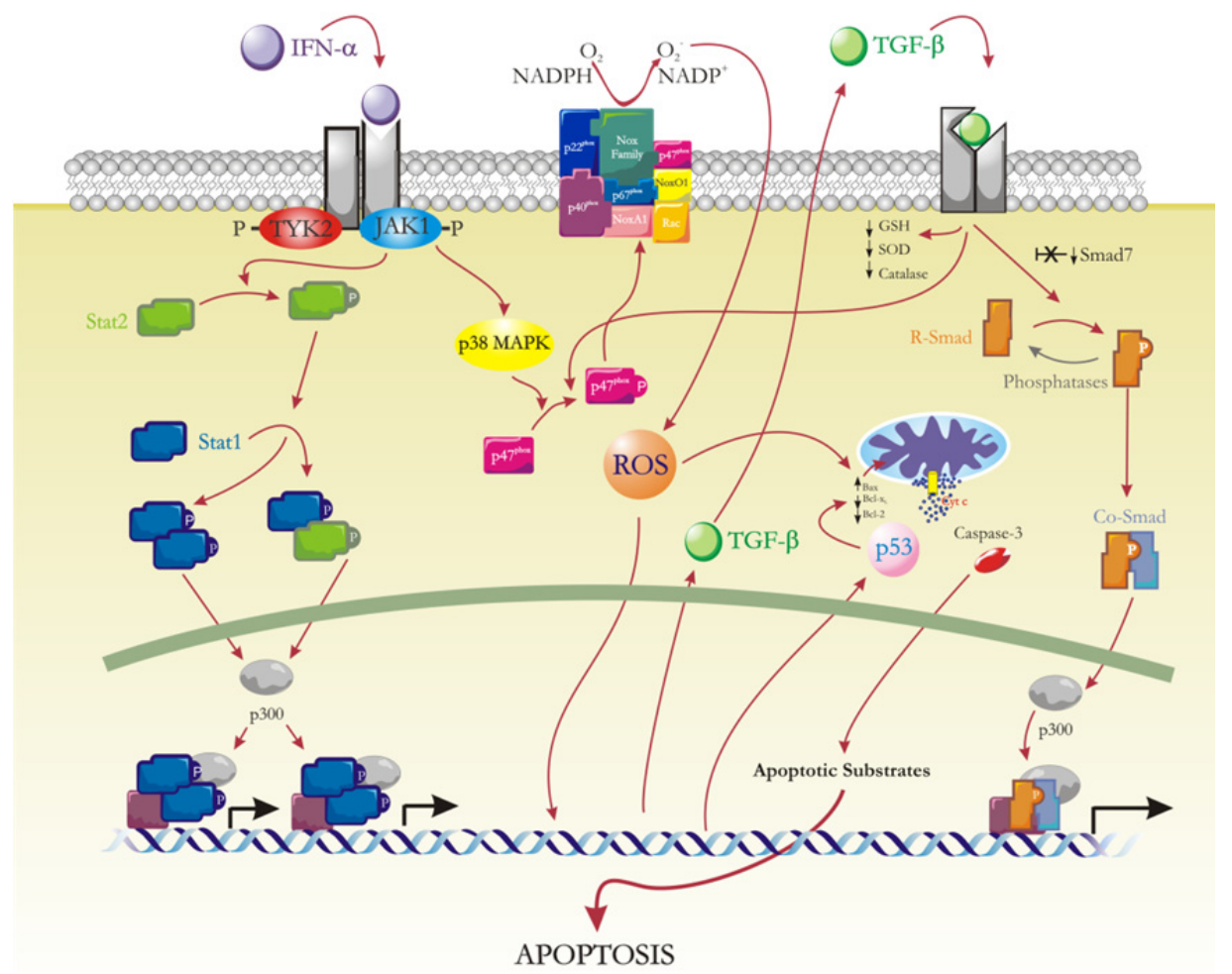

Figure 2. Graphic outline of IFN $\alpha$-2b, TGF $\beta 1$, p38 MAPK, NADPH oxidase and ROS interactions in liver preneoplasia.

The major findings of our studies were related to the impairment of the canonical $\mathrm{Wnt} / \beta$ catenin/TCF pathway in a very early stage of hepatic carcinogenesis. In addition, we demonstrated that in vivo IFN $\alpha-2 b$ treatment produces an attenuation of TCF transcriptional activity and enhances FOXO transcriptional activity in preneoplastic livers.

The common denominator of an abnormal Wnt signaling is the stabilization and accumulation of unphosphorylated $\beta$-catenin in the cytoplasm of a cell. Eventually, this allows entry of unphosphorylated $\beta$-catenin into the nucleus where it promotes the transcription of a subset of genes implicated in cellular proliferation. This $\beta$-catenin stabilization was demonstrated in our two-phase carcinogenic model, where plasma membrane delocalization and cytoplasmic accumulation of $\beta$-catenin were observed [119]. Moreover, significant reductions of phosphorylated $\beta$-catenin levels were found in IP animals. Since total $\beta$-catenin (phosphorylated and unphosphorylated) protein levels were preserved in all studied groups, these results indicate a lower phosphorylation rate of cytoplasmic $\beta$-catenin in IP rats. 
We have also found up-regulation of TCF target genes Cyclin D1, MMP-7, Axin 2, and SP5 in preneoplastic livers. Up-regulation of Cyclin D1 was predicted since this protein is an important regulator of cell cycle progression, and its activity is required for G1 to S-phase transition. Overexpression of this gene has been associated with the development and progression of several cancers [120]. In addition, it has been reported that overexpression of Cyclin D1 in tumor cells contributes with their resistance to cytotoxic drugs [121]. In fact, inhibition of Cyclin D1 enhances the effects of several chemotherapeutic agents [121]. In agreement with these results, we have previously described (see GSTs and liver preneoplasia: our first studies) a drug-resistance phenotype in isolated hepatocytes obtained from rat preneoplastic livers. Thus, it is possible that the overexpression of Cyclin D1 could play a role in the drug-resistance phenotype of this model. MMP-7, a member of the matrix metalloproteinase family, acts as a specific proteolytic enzyme for degradation of certain components of the extracellular matrix. This protein was already shown to be important for the growth of early adenomas [122] and its function is essential in more advanced stages such as tumor progression and metastasis, where an invasive growth is a highlight of these steps $[123,124]$. Hence, enhanced MMP-7 expression could be proposed as an indicator of potential tumor progression, invasiveness, and metastatic ability at a very early stage of hepatocarcinogenic development. It has been reported that the tumor suppressor Axin 2 is a target of Wnt signaling [125,126]. The up-regulation of Axin 2 showed in IP rats, which is known to be a negative regulator of free $\beta$-catenin $[127,128]$, could be an expression of a feedback preservation mechanism of the preneoplastic tissue, and might not be sufficient to prevent cytoplasmic $\beta$-catenin accumulation. SP5, a member of the SP1 transcription factor family and known target of Wnt signaling [129] was also over-expressed. This protein seems to work as a transcriptional repressor, preventing the expression of genes involved in cell cycle G1 phase arrest such as p21 [129].

In order to determine the involvement of a mutated $\beta$-catenin protein in the activation of this pathway as was described for HCC [130-133], we performed a direct sequencing of amplicons encoding a region of exon 2 of rat liver $\beta$-catenin gene. Our results demonstrated that this sequence had no deletion or point mutations in any of the studied groups.

Even with a wild-type $\beta$-catenin, the pathway can also be triggered because of alterations in other components of the cascade signaling. The Frizzled protein family acts as a seven-span transmembrane receptor for Wnt proteins. It was recently reported an up-regulation of the Frizzled-7 receptor in the presence of wild-type $\beta$-catenin in four murine transgenic models of hepatocarcinogenesis [134] and in human HCC [135] with activation of the Wnt/ $\beta$ catenin/TCF pathway. Therefore, it was suggested that overexpression of Frizzled-7 could lead or contribute to activation of Wnt signaling. The obtained data showed a marked increase of this receptor in preneoplastic livers at mRNA and protein levels. Since it was reported that Frizzled-7 is also a target gene of the Wnt/ $\beta$-catenin/TCF pathway [136], we presume that overexpression is rather a consequence than a cause of abnormal activation of the $\mathrm{Wnt} / \beta$-catenin/TCF pathway.

Once we demonstrated that the $\mathrm{Wnt} / \beta$-catenin/TCF pathway is activated in preneoplastic rat livers, we analyzed the effects of IFN $\alpha-2 b$ treatment. Results showed that in vivo IFN $\alpha-2 b$ 
administration did not prevent $\beta$-catenin delocalization and cytoplasmic accumulation; however, it certainly attenuates activation of the canonical Wnt/ $\beta$-catenin/TCF pathway as measured by four TCF target genes. The transcription levels of these genes were similar to controls in IP animals that received IFN $\alpha-2 b$.

In addition, IFN $\alpha$-2b-treated IP rats showed that Frizzled-7 levels remained unchanged compared to control animals. These results reinforced our hypothesis that Frizzled-7 upregulation occurs as a result of the abnormal activation of the studied pathway.

In an attempt to get more insight into the regulation of Wnt/ $\beta$-catenin/TCF pathway, FOXO transcription family has come into scene. Recent studies reported that FOXO interacts with $\beta$-catenin in a competitive manner with TCF, particularly under cellular oxidative stress conditions [137,138]. Taking this into consideration and the fact that in vivo IFN $\alpha-2 b$ treatment induces endogenous ROS formation in preneoplastic livers, we analyzed interactions between $\beta$-catenin with TCF4 and FoxO3a and association of these transcription factors with their corresponding target gene promoters. Co-immunoprecipitation assays showed that $\beta$-catenin/TCF4 interaction effectively occurs in preneoplastic livers and administration of IFN $\alpha-2 \mathrm{~b}$ not only attenuates this interaction but also promotes $\beta$ catenin/FoxO3a association. Using ChIP assay, we verified that interaction of FoxO3a with the promoter region of its target gene is enhanced in preneoplastic livers treated with IFN $\alpha$ $2 b$. On the other hand, TCF4 remains associated with SP5 gene promoter region in all studied groups. It is known that TCF4 contains a conserved domain that binds DNA irrespective of its interaction with $\beta$-catenin; however, the transcriptional activity is blocked by the presence of a family of transcriptional repressors $[139,140]$. TCF4 must bind $\beta$-catenin for its transactivation and this interaction was verified by co-immunoprecipitation assays. In addition, it has been demonstrated that interaction of $\beta$-catenin with FOXO enhances its transcriptional activity $[137,138]$, so we measured the expression of p130, a FOXO target gene whose main function is related to the maintenance of cell cycle arrest. Furthermore, it was suggested that p130 may exert a proapoptotic effect on certain tumor samples [141]. We found up-regulation of p130 transcript in preneoplastic livers treated with IFN $\alpha-2 b$. These findings suggest that IFN $\alpha-2 b$ treatment in preneoplastic livers decreases $\beta$-catenin/TCF interaction and consequently reduces TCF transcriptional activity probably via ROS induction. Furthermore, IFN $\alpha$-2b-induced ROS production could stimulate $\beta$-catenin/FOXO interaction, thereby favoring cell cycle arrest and apoptosis. In agreement with this proposal, recent unpublished results from our group demonstrate the participation of ROS in these events.

Collectively, our data demonstrate that the canonical Wnt/ $\beta$-catenin/TCF signaling pathway is activated at a very early stage of the development of the hepatocarcinogenic process, even with a wild-type $\beta$-catenin. More importantly, in vivo IFN $\alpha$-2b treatment could be an efficient therapy to attenuate $\mathrm{Wnt} / \beta$-catenin/TCF signaling promoting diminution of preneoplastic foci by an apoptotic process. A graphic outline of these concerns is shown in Figure 3. 


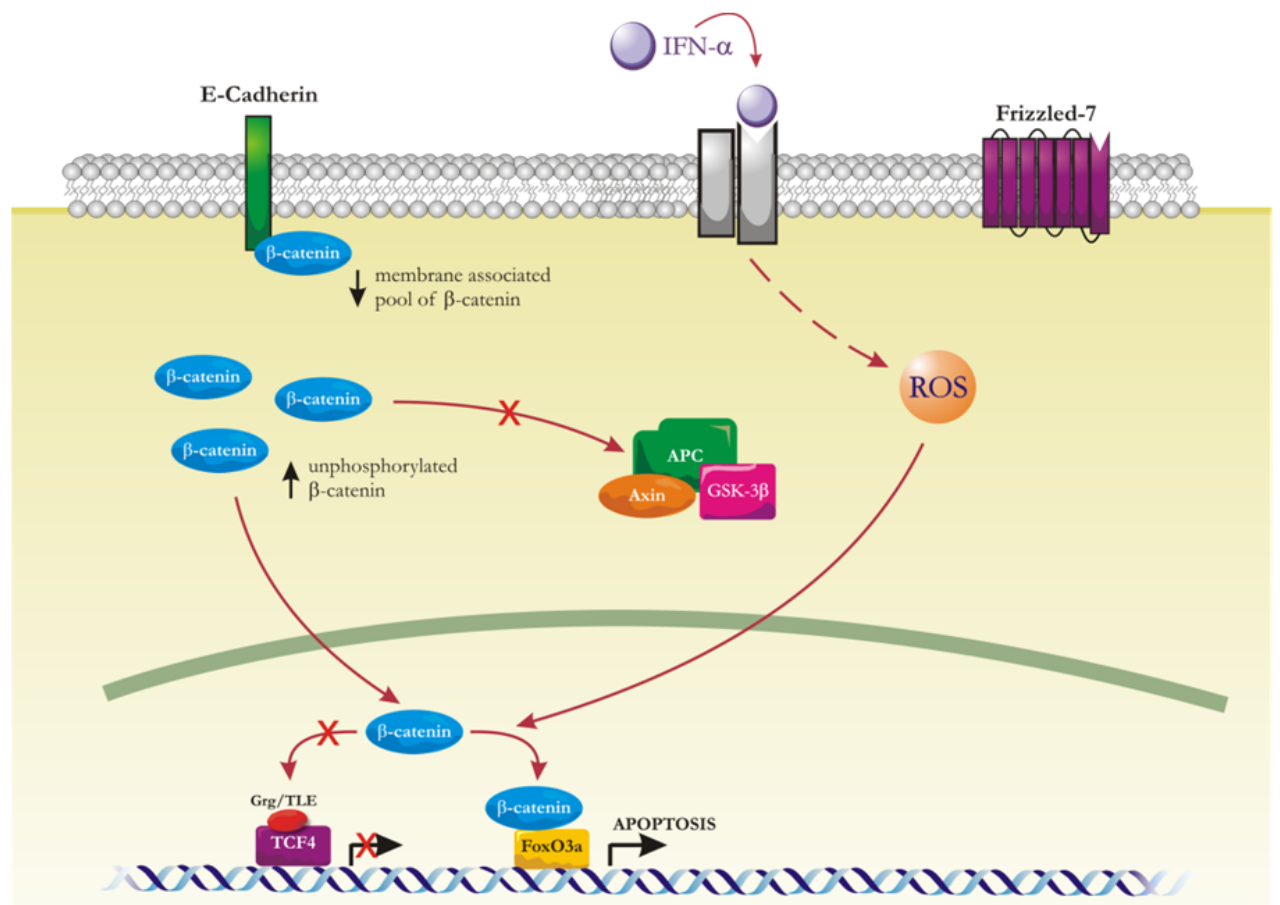

Figure 3. Graphic outline of IFN $\alpha-2 b$, Wnt/ $\beta$-catenin pathway and ROS/FOXO interactions in liver preneoplasia.

\section{Studies in HCC cell lines}

The elucidation of the signals induced by IFN $\alpha$ and TGF $\beta$ in human liver tumor cells, and their possible cross-talks with other intracellular signals, would have relevance in the future design of therapeutic tools to balance the cellular responses in favor of liver tumor suppression. To gain mechanistic insights into these cooperative signals, we analyzed the effects of IFN $\alpha-2 b$ and TGF $\beta 1$ on Wnt $/ \beta$-catenin pathway and Smads intermediates in HepG2/C3A and Huh7 HCC cell lines. We could demonstrate that IFN $\alpha-2 b$ or TGF $\beta 1$ stimulations not only decreased cellular proliferation but also increased apoptotic cell death [142]. The apoptotic and anti-proliferative effects of both cytokines separately have already been reported in HepG2 and Huh7 [143-145]. More interestingly, we demonstrated that the combined treatment increased these effects. Until now, combined treatment with both cytokines has only been used to analyze their impact on proliferation in human melanoma cell lines [109]. Treatments impact on $\mathrm{Wnt} / \beta$-catenin pathway was analyzed, together with the analysis of the effects of IFN $\alpha-2 b$ and TGF $\beta 1$ on Smads proteins. Insufficient 
information is available concerning TCF4/Smads association and their impact on carcinogenesis in HCC cell lines. Labbé et al. [146] and Letamendia et al. [147] reported the interaction between Smads 2, 3 and 4 and TCF/LEF in HepG2. Additionally, treatment with TGF $\beta 1$ in HepG2 reduced the amount of Smad4 protein bound to TCF/LEF and this was associated with the capacity of TGF $\beta 1$ of inhibiting cell proliferation [148]. To date, no study on IFN $\alpha$ and Smads has been carried out. More insight could be gained by analyzing the amount of each Smad protein inside the $\beta$-catenin/TCF4 nuclear complex, since all Smads coexist in this complex and the balance between them could contribute to the overall cell response by differently regulating gene expression as suggested by Edlund et al. [149].

Our findings clearly showed a negative modulation of IFN $\alpha-2 b$ and TGF $\beta 1$ on Wnt $/ \beta-$ catenin pathway. This attenuation was evidenced by a decrease in $\beta$-catenin and Frizzled-7 receptor proteins levels in $\mathrm{C} 3 \mathrm{~A}$ and Huh7 and by a diminution in the amount of $\beta$-catenin bound to TCF4. Stimulation with both cytokines also caused a decrease in Smads protein contents and their association with TCF4. This effect on Smads proteins seems to be linked to the decrease of $\beta$-catenin. Finally, the inhibition of $\beta$-catenin/TCF4/Smads complexes formation may have a critical role in slowing down oncogenesis, since the overall action of IFN $\alpha-2 b$ and/or TGF $\beta 1$ treatments on both HCC cell lines was the diminution in cellular proliferation and the increase in apoptotic cell death. In conclusion, our results support the efficacy of inhibiting Wnt/ $\beta$-catenin pathway in HCC cell lines through an IFN $\alpha-2 b$ and TGF $\beta 1$ combined treatment, proving that is effective against either wild-type or truncated $\beta$ catenin. These findings open a wide therapeutic option for patients with HCC.

\section{Summary \# 2}

The presented data suggest a model in which IFN $\alpha$-2b provides a link between TGF $\beta 1$ and Wnt signaling pathways and the oxidative stress/FOXO pathway. The stress caused by IFN $\alpha-2 \mathrm{~b}$ treatment might strengthen the interaction between FOXO and $\beta$-catenin and potentially inhibit the interaction with TCF and Smads. The inhibition of $\beta$ catenin/TCF4/Smads complexes formation may have a critical role in slowing down oncogenesis. These findings may have important clinical implications, since $\beta$-catenin, Smads, TCF, and FOXO arise as molecular targets for novel therapies that can modify their interactions favoring cellular apoptosis over proliferation in patients that underwent a potential carcinogenic hepatic injury.

\section{Concluding remarks: Oxidative stress as a critical factor in cancer therapy}

Preneoplastic hepatocytes are more resistant to oxidative stress than normal ones. Nevertheless, we demonstrated that increase in ROS levels triggered by IFN $\alpha$-2b enhances the process of programmed hepatocytes death, leading to the elimination of malignant cells. The study of the mechanism of IFN $\alpha$-2b-induced apoptosis led to demonstrate a link between TGF $\beta 1$ and Wnt signaling pathways and the oxidative stress/FOXO pathway. 
In conclusion, reactive oxygen species emerge as key mediators in the context of using cytokines as therapeutic agents in the treatment of human liver diseases, so the use of antioxidants could have the potential to decrease effectiveness of the therapy.

\section{Author details}

María Cristina Carrillo*, María de Luján Alvarez, Juan Pablo Parody, Ariel Darío Quiroga and María Paula Ceballos Institute of Experimental Physiology (IFISE-CONICET), Faculty of Biochemistry and Pharmacological Sciences, National University of Rosario, Rosario, Argentina

\section{Acknowledgement}

The authors kindly thank BioSidus Laboratory and Cassará Laboratory for the generous gift of recombinant IFN $\alpha-2 b$.

The work presented in this chapter was supported by research grants from Consejo Nacional de Investigaciones Científicas y Técnicas (CONICET) and from Agencia Nacional de Promoción Científica y Tecnológica (ANPCyT).

\section{References}

[1] Afanas'ev IB (2009) Signaling Mechanisms of Oxygen and Nitrogen Free Radicals. Boca Raton, FL, USA: CRC Press, Taylor \& Francis Group. 212 p.

[2] Motola-Kuba D, Zamora-Valdés D, Uribe M, Méndez-Sánchez N (2006) Hepatocellular carcinoma. An overview. Ann Hepatol. 5(1):16-24.

[3] Stewart H. (1975) Comparative aspects of certain cancers. In: Becker F, editor. Cancer. A Comprehensive Treatise. New York: Plenum Press. pp. 303-74.

[4] Williams GM (1989) The significance of chemically-induced hepatocellular altered foci in rat liver and application to carcinogen detection. Toxicol Pathol.17(4 Pt 1):663-72; discussion 673-4.

[5] Pitot HC, Campbell HA, Maronpot R, Bawa N, Rizvi TA, Xu YH, Sargent L, Dragan Y, Pyron M (1989) Critical parameters in the quantitation of the stages of initiation, promotion, and progression in one model of hepatocarcinogenesis in the rat. Toxicol Pathol. 17(4 Pt 1):594-611; discussion 611-2.

[6] Altmann HW. (1994) Hepatic neoformations. Pathol Res Pract. 190(6):513-77.

[7] Farber E, Sarma DS (1986) Chemical carcinogenesis: the liver as a model. Pathol Immunopathol Res. 5(1):1-28.

[8] Goldsworthy TL, Hanigan MH, Pitot HC (1986) Models of hepatocarcinogenesis in the rat--contrasts and comparisons. Crit Rev Toxicol.17(1):61-89.

[9] Solt D, Farber E. (1976) New principle for the analysis of chemical carcinogenesis. Nature. 263(5579):701-3.

\footnotetext{
${ }^{*}$ Corresponding Author
} 
[10] Ito N, Tsuda H, Tatematsu M, Inoue T, Tagawa Y, Aoki T, Uwagawa S, Kagawa M, Ogiso T, Masui T, et al. (1988) Enhancing effect of various hepatocarcinogens on induction of preneoplastic glutathione S-transferase placental form positive foci in rats-an approach for a new medium-term bioassay system. Carcinogenesis. 9(3):387-94.

[11] Rao PM, Nagamine Y, Roomi MW, Rajalakshmi S, Sarma DS (1984) Orotic acid, a new promoter for experimental liver carcinogenesis. Toxicol Pathol. 12(2):173-8.

[12] Peraino C, Staffeldt EF, Carnes BA, Ludeman VA, Blomquist JA, Vesselinovitch SD (1984) Characterization of histochemically detectable altered hepatocyte foci and their relationship to hepatic tumorigenesis in rats treated once with diethylnitrosamine or benzo(a)pyrene within one day after birth. Cancer Res. 44(8):3340-7.

[13] Pitot HC, Barsness L, Goldsworthy T, Kitagawa T (1978) Biochemical characterisation of stages of hepatocarcinogenesis after a single dose of diethylnitrosamine. Nature. 271(5644):456-8.

[14] de Luján Alvarez M, Cerliani JP, Monti J, Carnovale C, Ronco MT, Pisani G, Lugano MC, Carrillo MC. (2002) The in vivo apoptotic effect of interferon alfa-2b on rat preneoplastic liver involves Bax protein. Hepatology. 35(4):824-33.

[15] Parody JP, Alvarez M de L, Quiroga A, Ronco MT, Francés D, Carnovale C, Carrillo MC (2007) Hepatocytes isolated from preneoplastic rat livers are resistant to ethacrynic acid cytotoxicity. Arch Toxicol. 81(8):565-73.

[16] Imai $T$, Masui $T$, Ichinose $M$, Nakanishi $H$, Yanai $T$, Masegi $T$, Muramatsu $M$, Tatematsu M (1997) Reduction of glutathione S-transferase P-form mRNA expression in remodeling nodules in rat liver revealed by in situ hybridization. Carcinogenesis. 18(3):545-51.

[17] Pitot HC (1990) Altered hepatic foci: their role in murine hepatocarcinogenesis. Annu Rev Pharmacol Toxicol. 30:465-500.

[18] Coles B, Ketterer B (1990) The role of glutathione and glutathione transferases in chemical carcinogenesis. Crit Rev Biochem Mol Biol. 25(1):47-70.

[19] Mannervik B, Danielson UH (1988) Glutathione transferases--structure and catalytic activity. CRC Crit Rev Biochem. 23(3):283-337.

[20] Morrow CS, Cowan KH (1990) Glutathione S-transferases and drug resistance. Cancer Cells. 2(1):15-22.

[21] Keen JH, Jakoby WB (1978) Glutathione transferases. Catalysis of nucleophilic reactions of glutathione. J Biol Chem. 253(16):5654-7.

[22] Hayes JD, McLellan LI (1999) Glutathione and glutathione-dependent enzymes represent a co-ordinately regulated defence against oxidative stress. Free Radic Res. 31(4):273-300.

[23] Satoh K, Kitahara A, Soma Y, Inaba Y, Hatayama I, Sato K (1985) Purification, induction, and distribution of placental glutathione transferase: a new marker enzyme for preneoplastic cells in the rat chemical hepatocarcinogenesis. Proc Natl Acad Sci U S A. 82(12):3964-8.

[24] Armstrong DK, Gordon GB, Hilton J, Streeper RT, Colvin OM, Davidson NE (1992) Hepsulfam sensitivity in human breast cancer cell lines: the role of glutathione and glutathione S-transferase in resistance. Cancer Res. 52(6):1416-21. 
[25] Batist G, Tulpule A, Sinha BK, Katki AG, Myers CE, Cowan KH (1986) Overexpression of a novel anionic glutathione transferase in multidrug-resistant human breast cancer cells. J Biol Chem. 261(33):15544-9.

[26] Tolman KG, Gray PD, el Masry S, Luther RR, Janicki RS (1989) Toxicity of uricosuric diuretics in rat hepatocyte culture. Biochem Pharmacol. 38(7):1181-4.

[27] Yamamoto K, Masubuchi Y, Narimatsu S, Kobayashi S, Horie T (2002) Toxicity of ethacrynic acid in isolated rat hepatocytes. Toxicol In Vitro. 16(2):151-8.

[28] Evers R, Kool M, van Deemter L, Janssen H, Calafat J, Oomen LC, Paulusma CC, Oude Elferink RP, Baas F, Schinkel AH, Borst P (1998) Drug export activity of the human canalicular multispecific organic anion transporter in polarized kidney MDCK cells expressing cMOAT (MRP2) cDNA. J Clin Invest.101(7):1310-9.

[29] Tirona RG, Tan E, Meier G, Pang KS (1999) Uptake and glutathione conjugation of ethacrynic acid and efflux of the glutathione adduct by periportal and perivenous rat hepatocytes. J Pharmacol Exp Ther. 291(3):1210-9.

[30] Iersel ML, Ploemen JP, Struik I, van Amersfoort C, Keyzer AE, Schefferlie JG, van Bladeren PJ (1996) Inhibition of glutathione S-transferase activity in human melanoma cells by alpha,beta-unsaturated carbonyl derivatives. Effects of acrolein, cinnamaldehyde, citral, crotonaldehyde, curcumin, ethacrynic acid, and trans-2hexenal. Chem Biol Interact. 102(2):117-32.

[31] Ploemen JH, van Ommen B, van Bladeren PJ (1990) Inhibition of rat and human glutathione S-transferase isoenzymes by ethacrynic acid and its glutathione conjugate. Biochem Pharmacol. 40(7):1631-5.

[32] Ohkawa H, Ohishi N, Yagi K (1979) Assay for lipid peroxides in animal tissues by thiobarbituric acid reaction. Anal Biochem. 95(2):351-8.

[33] Sato K (1989) Glutathione transferases as markers of preneoplasia and neoplasia. Adv Cancer Res. 52:205-55.

[34] Meyer DJ, Beale D, Tan KH, Coles B, Ketterer B (1985) Glutathione transferases in primary rat hepatomas: the isolation of a form with GSH peroxidase activity. FEBS Lett. 184(1):139-43.

[35] Mannervik B, Alin P, Guthenberg C, Jensson H, Tahir MK, Warholm M, Jörnvall H (1985) Identification of three classes of cytosolic glutathione transferase common to several mammalian species: correlation between structural data and enzymatic properties. Proc Natl Acad Sci U S A. 82(21):7202-6.

[36] Tahir MK, Guthenberg C, Mannervik B (1989) Glutathione transferases in rat hepatoma cells. Effects of ascites cells on the isoenzyme pattern in liver and induction of glutathione transferases in the tumour cells. Biochem J. 257(1):215-20.

[37] Kuzmich S, Vanderveer LA, Walsh ES, LaCreta FP, Tew KD (1992) Increased levels of glutathione S-transferase pi transcript as a mechanism of resistance to ethacrynic acid. Biochem J. 281(Pt 1):219-24.

[38] Morrow CS, Smitherman PK, Townsend AJ (1998) Combined expression of multidrug resistance protein (MRP) and glutathione S-transferase P1-1 (GSTP1-1) in MCF7 cells and high level resistance to the cytotoxicities of ethacrynic acid but not oxazaphosphorines or cisplatin. Biochem Pharmacol. 56(8):1013-21. 
[39] Nies AT, König J, Pfannschmidt M, Klar E, Hofmann WJ, Keppler D (2001) Expression of the multidrug resistance proteins MRP2 and MRP3 in human hepatocellular carcinoma. Int J Cancer. 94(4):492-9.

[40] Ji B, Ito K, Sekine S, Tajima A, Horie T (2004) Ethacrynic-acid-induced glutathione depletion and oxidative stress in normal and Mrp2-deficient rat liver. Free Radic Biol Med. 37(11):1718-29.

[41] Favre C, Carnovale CE, Monti JA, Carrillo MC (2001) Inhibition by interferon alpha-2b of rat liver regeneration: effect on ornithine decarboxylase and total protein synthesis. Biochem Pharmacol. 61(12):1587-93.

[42] Rosemberg S (1997) Principles of cancer management: biologic therapy. In: De Vita V, Hellman S RS, editors. Cancer: Principles and Practice of Oncology. Philadelphia: Lippincott-Raven. pp. 349-73.

[43] Ikeda K, Saitoh S, Suzuki Y, Kobayashi M, Tsubota A, Fukuda M, Koida I, Arase Y, Chayama K, Murashima N, Kumada H (1998) Interferon decreases hepatocellular carcinogenesis in patients with cirrhosis caused by the hepatitis B virus: a pilot study. Cancer. 82(5):827-35.

[44] Yoshida H, Shiratori Y, Moriyama M, Arakawa Y, Ide T, Sata M, Inoue O, Yano M, Tanaka M, Fujiyama S, Nishiguchi S, Kuroki T, Imazeki F, Yokosuka O, Kinoyama S, Yamada G, Omata M (1999) Interferon therapy reduces the risk for hepatocellular carcinoma: national surveillance program of cirrhotic and noncirrhotic patients with chronic hepatitis C in Japan. IHIT Study Group. Inhibition of Hepatocarcinogenesis by Interferon Therapy. Ann Intern Med. 131(3):174-81.

[45] Lai CL, Lau JY, Wu PC, Ngan H, Chung HT, Mitchell SJ, Corbett TJ, Chow AW, Lin HJ (1993) Recombinant interferon-alpha in inoperable hepatocellular carcinoma: a randomized controlled trial. Hepatology. 17(3):389-94.

[46] Llovet JM, Sala M, Castells L, Suarez Y, Vilana R, Bianchi L, Ayuso C, Vargas V, Rodés J, Bruix J (2000) Randomized controlled trial of interferon treatment for advanced hepatocellular carcinoma. Hepatology. 31(1):54-8.

[47] Dunk AA, Ikeda T, Pignatelli M, Thomas HC (1986) Human lymphoblastoid interferon. In vitro and in vivo studies in hepatocellular carcinoma. J Hepatol. 2(3):419-29.

[48] Yano H, Iemura A, Haramaki M, Ogasawara S, Takayama A, Akiba J, Kojiro M (1999) Interferon alfa receptor expression and growth inhibition by interferon alfa in human liver cancer cell lines. Hepatology. 29(6):1708-17.

[49] Murphy D, Detjen KM, Welzel M, Wiedenmann B, Rosewicz S (2001) Interferon-alpha delays S-phase progression in human hepatocellular carcinoma cells via inhibition of specific cyclin-dependent kinases. Hepatology. 33(2):346-56.

[50] Gutterman JU (1994) Cytokine therapeutics: lessons from interferon alpha. Proc Natl Acad Sci U S A. 91(4):1198-205.

[51] Creasey AA, Bartholomew JC, Merigan TC (1980) Role of G0-G1 arrest in the inhibition of tumor cell growth by interferon. Proc Natl Acad Sci U S A. 77(3):1471-5.

[52] Roos G, Leanderson T, Lundgren E (1984) Interferon-induced cell cycle changes in human hematopoietic cell lines and fresh leukemic cells. Cancer Res. 44(6):2358-62.

[53] Soini Y, Pääkkö P, Lehto VP (1998) Histopathological evaluation of apoptosis in cancer. Am J Pathol. 153(4):1041-53. 
[54] Schulte-Hermann R, Grasl-Kraupp B, Bursch W (1995) Apoptosis and hepatocarcinogenesis. In: Jirtle J, editor. Liver Regeneration and Carcinogenesis. San Diego: Academic. pp. 141-78.

[55] Miyashita T, Harigai M, Hanada M, Reed JC (1994) Identification of a p53-dependent negative response element in the bcl-2 gene. Cancer Res. 54(12):3131-5.

[56] Miyashita T, Reed JC (1995) Tumor suppressor p53 is a direct transcriptional activator of the human bax gene. Cell. 80(2):293-9.

[57] Sangfelt O, Erickson S, Castro J, Heiden T, Einhorn S, Grandér D (1997) Induction of apoptosis and inhibition of cell growth are independent responses to interferon-alpha in hematopoietic cell lines. Cell Growth Differ. 8(3):343-52.

[58] Rodríguez-Villanueva J, McDonnell TJ (1995) Induction of apoptotic cell death in nonmelanoma skin cancer by interferon-alpha. Int J Cancer. 61(1):110-4.

[59] Sedlak TW, Oltvai ZN, Yang E, Wang K, Boise LH, Thompson CB, Korsmeyer SJ (1995) Multiple Bcl-2 family members demonstrate selective dimerizations with Bax. Proc Natl Acad Sci U S A.92(17):7834-8.

[60] Yang J, Liu X, Bhalla K, Kim CN, Ibrado AM, Cai J, Peng TI, Jones DP, Wang X (1997) Prevention of apoptosis by Bcl-2: release of cytochrome c from mitochondria blocked. Science. 275(5303):1129-32.

[61] Nechushtan A, Smith CL, Hsu YT, Youle RJ (1999) Conformation of the Bax C-terminus regulates subcellular location and cell death. EMBO J. 18(9):2330-41.

[62] Shima Y, Nakao K, Nakashima T, Kawakami A, Nakata K, Hamasaki K, Kato Y, Eguchi K, Ishii N (1999) Activation of caspase-8 in transforming growth factor-beta-induced apoptosis of human hepatoma cells. Hepatology. 30(5):1215-22.

[63] Yamamoto M, Fukuda K, Miura N, Suzuki R, Kido T, Komatsu Y (1998) Inhibition by dexamethasone of transforming growth factor beta1-induced apoptosis in rat hepatoma cells: a possible association with Bcl-xL induction. Hepatology. 27(4):959-66.

[64] Buenemann CL, Willy C, Buchmann A, Schmiechen A, Schwarz M (2001) Transforming growth factor-beta1-induced Smad signaling, cell-cycle arrest and apoptosis in hepatoma cells. Carcinogenesis. 22(3):447-52.

[65] Gressner AM, Lahme B, Mannherz HG, Polzar B (1997) TGF-beta-mediated hepatocellular apoptosis by rat and human hepatoma cells and primary rat hepatocytes. J Hepatol. 26(5):1079-92.

[66] Rossmanith W, Schulte-Hermann R (2001) Biology of transforming growth factor beta in hepatocarcinogenesis. Microsc Res Tech. 52(4):430-6.

[67] Kanzler S, Meyer E, Lohse AW, Schirmacher P, Henninger J, Galle PR, Blessing M (2001) Hepatocellular expression of a dominant-negative mutant TGF-beta type II receptor accelerates chemically induced hepatocarcinogenesis. Oncogene. 20(36):501524.

[68] Matsuzaki K, Date M, Furukawa F, Tahashi Y, Matsushita M, Sakitani K, Yamashiki N, Seki T, Saito H, Nishizawa M, Fujisawa J, Inoue K (2000) Autocrine stimulatory mechanism by transforming growth factor beta in human hepatocellular carcinoma. Cancer Res. 60(5):1394-402.

[69] Santoni-Rugiu E, Jensen MR, Factor VM, Thorgeirsson SS (1999) Acceleration of c-mycinduced hepatocarcinogenesis by Co-expression of transforming growth factor (TGF)- 
alpha in transgenic mice is associated with TGF-beta1 signaling disruption. Am J Pathol. 154(6):1693-700.

[70] Grasl-Kraupp B, Rossmanith W, Ruttkay-Nedecky B, Müllauer L, Kammerer B, Bursch W, Schulte-Hermann R (1998) Levels of transforming growth factor beta and transforming growth factor beta receptors in rat liver during growth, regression by apoptosis and neoplasia. Hepatology. 28(3):717-26.

[71] Huang YL, Chou CK (1998) Bcl-2 blocks apoptotic signal of transforming growth factorbeta in human hepatoma cells. J Biomed Sci. 5(3):185-91.

[72] de Luján Alvarez M, Ronco MT, Ochoa JE, Monti J a, Carnovale CE, Pisani GB, Lugano MC, Carrillo MC (2004) Interferon alpha-induced apoptosis on rat preneoplastic liver is mediated by hepatocytic transforming growth factor beta(1). Hepatology. 40(2):394-402.

[73] Hori Y, Takeyama Y, Ueda T, Shinkai M, Takase K, Kuroda Y (2000) Macrophagederived transforming growth factor-beta1 induces hepatocellular injury via apoptosis in rat severe acute pancreatitis. Surgery. 127(6):641-9.

[74] Kamimura S, Tsukamoto H (1995) Cytokine gene expression by Kupffer cells in experimental alcoholic liver disease. Hepatology. 22(4 Pt 1):1304-9.

[75] Gao C, Gressner G, Zoremba M, Gressner AM (1996) Transforming growth factor beta (TGF-beta) expression in isolated and cultured rat hepatocytes. J Cell Physiol. 167(3):394-405.

[76] Matsuzaki K, Date M, Furukawa F, Tahashi Y, Matsushita M, Sugano Y, Yamashiki N, Nakagawa T, Seki T, Nishizawa M, Fujisawa J, Inoue K (2000) Regulatory mechanisms for transforming growth factor beta as an autocrine inhibitor in human hepatocellular carcinoma: implications for roles of smads in its growth. Hepatology. 32(2):218-27.

[77] Bissell DM, Wang SS, Jarnagin WR, Roll FJ (1995) Cell-specific expression of transforming growth factor-beta in rat liver. Evidence for autocrine regulation of hepatocyte proliferation. J Clin Invest. 96(1):447-55.

[78] Babior BM (2000) The NADPH oxidase of endothelial cells. IUBMB Life. 50(4-5):267-9.

[79] Quiroga AD, Alvarez MDL, Parody JP, Ronco MT, Francés DE, Pisani GB, Carnovale CE, Carrillo MC (2007) Involvement of reactive oxygen species on the apoptotic mechanism induced by IFN-alpha2b in rat preneoplastic liver. Biochem Pharmacol.73(11):1776-85.

[80] Herrera B, Murillo MM, Alvarez-Barrientos A, Beltrán J, Fernández M, Fabregat I (2004) Source of early reactive oxygen species in the apoptosis induced by transforming growth factor-beta in fetal rat hepatocytes. Free Radical Biol Med. 36(1):16-26.

[81] Park CH (1988) Vitamin C in leukemia and preleukemia cell growth. Prog Clin Biol Res. 259:321-30.

[82] Prasad KN, Kumar R (1996) Effect of individual and multiple antioxidant vitamins on growth and morphology of human nontumorigenic and tumorigenic parotid acinar cells in culture. Nutr Cancer. 26(1):11-9.

[83] Seifried HE, McDonald SS, Anderson DE, Greenwald P, Milner JA (2003) The antioxidant conundrum in cancer. Cancer Res. 63(15):4295-8.

[84] Uddin S, Majchrzak B, Woodson J, Arunkumar P, Alsayed Y, Pine R, Young PR, Fish EN, Platanias LC (1999) Activation of the p38 mitogen-activated protein kinase by type I interferons. J Biol Chem. 274(42):30127-31. 
[85] Sarkar D, Su Z-Z, Lebedeva IV, Sauane M, Gopalkrishnan RV, Valerie K, Dent P, Fisher PB (2002) mda-7 (IL-24) Mediates selective apoptosis in human melanoma cells by inducing the coordinated overexpression of the GADD family of genes by means of p38 MAPK. Proc Natl Acad Sci U S A. 99(15):10054-9.

[86] Porras A, Zuluaga S, Black E, Valladares A, Alvarez AM, Ambrosino C, Benito M, Nebreda AR (2005) P38 alpha mitogen-activated protein kinase sensitizes cells to apoptosis induced by different stimuli. Mol Biol Cell. 15(2):922-33.

[87] Liu B, Fang M, Lu Y, Mills GB, Fan Z (2001) Involvement of JNK-mediated pathway in EGF-mediated protection against paclitaxel-induced apoptosis in SiHa human cervical cancer cells. Br J Cancer. 85(2):303-11.

[88] Park JM, Greten FR, Li Z-W, Karin M (2002) Macrophage apoptosis by anthrax lethal factor through p38 MAP kinase inhibition. Science. 297(5589):2048-51.

[89] Juretic N, Santibáñez JF, Hurtado C, Martínez J (2001) ERK 1,2 and p38 pathways are involved in the proliferative stimuli mediated by urokinase in osteoblastic SaOS-2 cell line. J Cell Biochem. 83(1):92-8.

[90] Yosimichi G, Nakanishi T, Nishida T, Hattori T, Takano-Yamamoto T, Takigawa M (2001) CTGF/Hcs24 induces chondrocyte differentiation through a p38 mitogenactivated protein kinase (p38MAPK), and proliferation through a p44/42 MAPK/extracellular-signal regulated kinase (ERK). Eur J Biochem. 268(23):6058-65.

[91] Razandi M, Pedram A, Levin ER (2000) Estrogen signals to the preservation of endothelial cell form and function. J Biol Chem. 275(49):38540-6.

[92] Jiménez B, Volpert OV, Crawford SE, Febbraio M, Silverstein RL, Bouck N (2000) Signals leading to apoptosis-dependent inhibition of neovascularization by thrombospondin-1. Nat Med. 6(1):41-8.

[93] Nakagami H, Morishita R, Yamamoto K, Yoshimura SI, Taniyama Y, Aoki M, Matsubara H, Kim S, Kaneda Y, Ogihara T (2001) Phosphorylation of p38 mitogenactivated protein kinase downstream of bax-caspase-3 pathway leads to cell death induced by high D-glucose in human endothelial cells. Diabetes. 50(6):1472-81.

[94] Grethe S, Ares MPS, Andersson T, Pörn-Ares MI (2004) p38 MAPK mediates TNFinduced apoptosis in endothelial cells via phosphorylation and downregulation of Bclx(L). Exp Cell Res. 298(2):632-42.

[95] Verma A, Deb DK, Sassano A, Uddin S, Varga J, Wickrema A, Platanias LC (2002) Activation of the p38 mitogen-activated protein kinase mediates the suppressive effects of type I interferons and transforming growth factor-beta on normal hematopoiesis. J Biol Chem. 277(10):7726-35.

[96] Herrera B, Fernández M, Roncero C, Ventura JJ, Porras A, Valladares A, Benito M, Fabregat I (2001) Activation of p38MAPK by TGF-beta in fetal rat hepatocytes requires radical oxygen production, but is dispensable for cell death. FEBS Lett. 499(3):225-9.

[97] Bulavin DV, Demidov ON, Saito S, Kauraniemi P, Phillips C, Amundson SA, Ambrosino C, Sauter G, Nebreda AR, Anderson CW, Kallioniemi A, Fornace AJ Jr, Appella E (2002) Amplification of PPM1D in human tumors abrogates p53 tumorsuppressor activity. Nat Genet. 31(2):210-5.

[98] Bulavin DV, Phillips C, Nannenga B, Timofeev O, Donehower LA, Anderson CW, Appella E, Fornace AJ Jr (2004) Inactivation of the Wip1 phosphatase inhibits mammary 
tumorigenesis through p38 MAPK-mediated activation of the p16(Ink4a)-p19(Arf) pathway. Nat Genet. 36(4):343-50.

[99] Honmo S, Ozaki A, Yamamoto M, Hashimoto N, Miyakoshi M, Tanaka H, Yoshie M, Tamakawa S, Tokusashi Y, Yaginuma Y, Kasai S, Ogawa K (2007) Low p38 MAPK and JNK activation in cultured hepatocytes of DRH rats; a strain highly resistant to hepatocarcinogenesis. Mol Carcinog. 46(9):758-65.

[100] Mayer IA, Verma A, Grumbach IM, Uddin S, Lekmine F, Ravandi F, Majchrzak B, Fujita S, Fish EN, Platanias LC (2001) The p38 MAPK pathway mediates the growth inhibitory effects of interferon-alpha in BCR-ABL-expressing cells. J Biol Chem. 276(30):28570-7.

[101] Quiroga AD, de Lujan Alvarez M, Parody JP, Ronco MT, Carnovale CE, Carrillo MC (2009) Interferon-alpha2b (IFN-alpha2b)-induced apoptosis is mediated by p38 MAPK in hepatocytes from rat preneoplastic liver via activation of NADPH oxidase. Growth Factors. 27(4):214-27.

[102] Ulloa L, Doody J, Massagué J (1999) Inhibition of transforming growth factorbeta/SMAD signalling by the interferon-gamma/STAT pathway. Nature. 397(6721):710-3.

[103] Ghosh AK, Yuan W, Mori Y, Chen Sj, Varga J (2001) Antagonistic regulation of type I collagen gene expression by interferon-gamma and transforming growth factor-beta. Integration at the level of p300/CBP transcriptional coactivators. J Biol Chem. 276(14):11041-8.

[104] Higashi K, Inagaki Y, Fujimori K, Nakao A, Kaneko H, Nakatsuka I (2003) Interferongamma interferes with transforming growth factor-beta signaling through direct interaction of YB-1 with Smad3. J Biol Chem. 278(44):43470-9.

[105] Ishida Y, Kondo T, Takayasu T, Iwakura Y, Mukaida N (2004) The essential involvement of cross-talk between IFN-gamma and TGF-beta in the skin woundhealing process. J Immunol. 172(3):1848-55.

[106] Jeong W-I, Park O, Radaeva S, Gao B (2006) STAT1 inhibits liver fibrosis in mice by inhibiting stellate cell proliferation and stimulating NK cell cytotoxicity. Hepatology. 44(6):1441-51.

[107] Weng H, Mertens PR, Gressner AM, Dooley S (2007) IFN-gamma abrogates profibrogenic TGF-beta signaling in liver by targeting expression of inhibitory and receptor Smads. J Hepatol. 46(2):295-303.

[108] Yamamoto T, Matsuda T, Muraguchi A, Miyazono K, Kawabata M (2001) Cross-talk between IL-6 and TGF-beta signaling in hepatoma cells. FEBS Lett. 492(3):247-53.

[109] Foser S, Redwanz I, Ebeling M, Heizmann CW, Certa U (2006) Interferon-alpha and transforming growth factor-beta co-induce growth inhibition of human tumor cells. Cell Mol Life Sci. 63(19-20):2387-96.

[110] Roberts AB, Wakefield LM (2003) The two faces of transforming growth factor beta in carcinogenesis. Proc Natl Acad Sci U S A. 100(15):8621-3.

[111] Lei X, Yang J, Nichols RW, Sun L-Z (2007) Abrogation of TGFbeta signaling induces apoptosis through the modulation of MAP kinase pathways in breast cancer cells. Exp Cell Res. 313(8):1687-95. 
[112] Park DY, Lee CH, Sol MY, Suh KS, Yoon SY, Kim JW (2003) Expression and localization of the transforming growth factor-beta type I receptor and Smads in preneoplastic lesions during chemical hepatocarcinogenesis in rats. J Korean Med Sci. 18(4):510-9.

[113] Alvarez MDL, Quiroga AD, Parody JP, Ronco MT, Francés DE, Carnovale CE, Carrillo MC (2009) Cross-talk between IFN-alpha and TGF-beta1 signaling pathways in preneoplastic rat liver. Growth Factors. 27(1):1-11.

[114] Kim SJ, Im YH, Markowitz SD, Bang YJ (2000) Molecular mechanisms of inactivation of TGF-beta receptors during carcinogenesis. Cytokine Growth Factor Rev. 11(1-2):15968.

[115] Ghosh AK, Varga J (2007) The transcriptional coactivator and acetyltransferase p300 in fibroblast biology and fibrosis. J Cell Physiol. 213(3):663-71.

[116] Inagaki Y, Nemoto T, Kushida M, Sheng Y, Higashi K, Ikeda K, Kawada N, Shirasaki F, Takehara K, Sugiyama K, Fujii M, Yamauchi H, Nakao A, de Combrugghe B, Watanabe T, Okazaki I (2003) Interferon alfa down-regulates collagen gene transcription and suppresses experimental hepatic fibrosis in mice. Hepatology. 38(4):890-9.

[117] Alvarez MDL, Quiroga AD, Ronco MT, Parody JP, Ochoa JE, Monti JA, Carnovale CE, Carrillo MC (2006) Time-dependent onset of Interferon-alpha2b-induced apoptosis in isolated hepatocytes from preneoplastic rat livers. Cytokine. 36(5-6):245-53.

[118] Nambotin SB, Wands JR, Kim M (2011) Points of therapeutic intervention along the Wnt signaling pathway in hepatocellular carcinoma. Anticancer Agents Med Chem. 11(6):549-59.

[119] Parody JP, Alvarez ML, Quiroga AD, Ceballos MP, Frances DE, Pisani GB, Pellegrino JM, Carnovale CE, Carrillo MC (2010) Attenuation of the Wnt/beta-catenin/TCF pathway by in vivo interferon-alpha2b (IFN-alpha2b) treatment in preneoplastic rat livers. Growth Factors. 28(3):166-77.

[120] Gautschi O, Ratschiller D, Gugger M, Betticher DC, Heighway J (2007) Cyclin D1 in non-small cell lung cancer: a key driver of malignant transformation. Lung Cancer. 55(1):1-14.

[121] Kornmann M, Danenberg KD, Arber N, Beger HG, Danenberg PV, Korc M (1999) Inhibition of cyclin D1 expression in human pancreatic cancer cells is associated with increased chemosensitivity and decreased expression of multiple chemoresistance genes. Cancer Res. 59(14):3505-11.

[122] Wilson CL, Heppner KJ, Labosky P a, Hogan BL, Matrisian LM (1997) Intestinal tumorigenesis is suppressed in mice lacking the metalloproteinase matrilysin. Proc Natl Acad Sci U S A.94(4):1402-7.

[123] Powell WC, Knox JD, Navre M, Grogan TM, Kittelson J, Nagle RB, Bowden GT (1993) Expression of the metalloproteinase matrilysin in DU-145 cells increases their invasive potential in severe combined immunodeficient mice. Cancer Res. 53(2):417-22.

[124] Yamamoto H, Itoh F, Hinoda Y, Imai K (1995) Suppression of matrilysin inhibits colon cancer cell invasion in vitro. Int J Cancer. 61(2):218-22.

[125] Yan D, Wiesmann M, Rohan M, Chan V, Jefferson AB, Guo L, Sakamoto D, Caothien RH, Fuller JH, Reinhard C, Garcia PD, Randazzo FM, Escobedo J, Fantl WJ, Williams 
LT (2001) Elevated expression of axin2 and hnkd mRNA provides evidence that Wnt/beta -catenin signaling is activated in human colon tumors. Proc Natl Acad Sci U S A. 98(26):14973-8.

[126] Jho E-hoon, Zhang T, Domon C, Joo C-K, Freund J-N, Costantini F (2002) Wnt/betacatenin/Tcf signaling induces the transcription of Axin2, a negative regulator of the signaling pathway. Mol Cell Biol. 22(4):1172-83.

[127] Behrens J (1998) Functional Interaction of an Axin Homolog, Conductin, with -Catenin, APC, and GSK3. Science. 280(5363):596-9.

[128] Hart MJ, de los Santos R, Albert IN, Rubinfeld B, Polakis P (1998) Downregulation of beta-catenin by human Axin and its association with the APC tumor suppressor, betacatenin and GSK3 beta. Curr Biol. 8(10):573-81.

[129] Fujimura N, Vacik T, Machon O, Vlcek C, Scalabrin S, Speth M, Diep D, Krauss S, Kozmik Z (2007) Wnt-mediated down-regulation of Sp1 target genes by a transcriptional repressor Sp5. J Biol Chem. 282(2):1225-37.

[130] de La Coste A, Romagnolo B, Billuart P, Renard CA, Buendia MA, Soubrane O, Fabre M, Chelly J, Beldjord C, Kahn A, Perret C (1998) Somatic mutations of the beta-catenin gene are frequent in mouse and human hepatocellular carcinomas. Proc Natl Acad Sci U S A. 95(15):8847-51.

[131] Miyoshi Y, Iwao K, Nagasawa Y, Aihara T, Sasaki Y, Imaoka S, Murata M, Shimano T, Nakamura Y (1998) Activation of the beta-catenin gene in primary hepatocellular carcinomas by somatic alterations involving exon 3. Cancer Res. 58(12):2524-7.

[132] Devereux TR, Anna CH, Foley JF, White CM, Sills RC, Barrett JC (1999) Mutation of beta-catenin is an early event in chemically induced mouse hepatocellular carcinogenesis. Oncogene. 18(33):4726-33.

[133] Calvisi DF, Factor VM, Loi R, Thorgeirsson SS (2001) Activation of beta-catenin during hepatocarcinogenesis in transgenic mouse models: relationship to phenotype and tumor grade. Cancer Res. 61(5):2085-91.

[134] Merle P, Kim M, Herrmann M, Gupte A, Lefrançois L, Califano S, Trépo C, Tanaka S, Vitvitski L, de la Monte S, Wands JR (2005) Oncogenic role of the frizzled-7/betacatenin pathway in hepatocellular carcinoma. J Hepatol. 43(5):854-62.

[135] Merle P, de la Monte S, Kim M, Herrmann M, Tanaka S, Von Dem Bussche A, Kew MC, Trepo C, Wands JR (2004) Functional consequences of frizzled-7 receptor overexpression in human hepatocellular carcinoma. Gastroenterology. 127(4):1110-22.

[136] Willert J, Epping M, Pollack JR, Brown PO, Nusse R (2002) A transcriptional response to Wnt protein in human embryonic carcinoma cells. BMC Dev Biol. 2:8.

[137] Essers MAG, de Vries-Smits LMM, Barker N, Polderman PE, Burgering BMT, Korswagen HC (2005) Functional interaction between beta-catenin and FOXO in oxidative stress signaling. Science. 308(5725):1181-4.

[138] Hoogeboom D, Essers MAG, Polderman PE, Voets E, Smits LMM, Burgering BMT (2008) Interaction of FOXO with beta-catenin inhibits beta-catenin/T cell factor activity. J Biol Chem. 283(14):9224-30.

[139] Cavallo RA, Cox RT, Moline MM, Roose J, Polevoy GA, Clevers H, Peifer M, Bejsovec A (1998) Drosophila Tcf and Groucho interact to repress Wingless signalling activity. Nature. 395(6702):604-8. 
[140] Levanon D, Goldstein RE, Bernstein Y, Tang H, Goldenberg D, Stifani S, Paroush Z, Groner Y (1998) Transcriptional repression by AML1 and LEF-1 is mediated by the TLE/Groucho corepressors. Proc Natl Acad Sci U S A. 95(20):11590-5.

[141] Bellan C, De Falco G, Tosi GM, Lazzi S, Ferrari F, Morbini G, Bartolomei S, Toti P, Mangiavacchi P, Cevenini G, Trimarchi C, Cinti C, Giordano A, Leoncini L, Tosi P, Cottier H (2002) Missing expression of pRb2/p130 in human retinoblastomas is associated with reduced apoptosis and lesser differentiation. Invest Ophthalmol Vis Sci. 43(12):3602-8.

[142] Ceballos MP, Parody JP, Alvarez MDL, Ingaramo PI, Carnovale CE, Carrillo MC (2011) Interferon- $\alpha 2 b$ and transforming growth factor- $\beta 1$ treatments on HCC cell lines: Are Wnt/ $\beta$-catenin pathway and Smads signaling connected in hepatocellular carcinoma? Biochem Pharmacol. 82(11):1682-91.

[143] Damdinsuren B, Nagano H, Kondo M, Natsag J, Hanada H, Nakamura M, Wada H, Kato H, Marubashi S, Miyamoto A, Takeda Y, Umeshita K, Dono K, Monden M (2006) TGF-beta1-induced cell growth arrest and partial differentiation is related to the suppression of Id1 in human hepatoma cells. Oncol Rep. 15(2):401-8.

[144] Ho J, Cocolakis E, Dumas VM, Posner BI, Laporte SA, Lebrun J-J (2005) The G proteincoupled receptor kinase-2 is a TGFbeta-inducible antagonist of TGFbeta signal transduction. EMBO J. 24(18):3247-58.

[145] Murata M, Nabeshima S, Kikuchi K, Yamaji K, Furusyo N, Hayashi J (2006) A comparison of the antitumor effects of interferon-alpha and beta on human hepatocellular carcinoma cell lines. Cytokine. 33(3):121-8.

[146] Labbé E, Letamendia A, Attisano L (2000) Association of Smads with lymphoid enhancer binding factor $1 / \mathrm{T}$ cell-specific factor mediates cooperative signaling by the transforming growth factor-beta and wnt pathways. Proc Natl Acad Sci U S A. 97(15):8358-63.

[147] Letamendia A, Labbé E, Attisano L (2001) Transcriptional regulation by Smads: crosstalk between the TGF-beta and Wnt pathways. J Bone Joint Surg Am. 83-A Suppl(Pt 1):S31-9.

[148] Lim SK, Hoffmann FM (2006) Smad4 cooperates with lymphoid enhancer-binding factor $1 / \mathrm{T}$ cell-specific factor to increase c-myc expression in the absence of TGF-beta signaling. Proc Natl Acad Sci U S A. 103(49):18580-5.

[149] Edlund S, Lee SY, Grimsby S, Zhang S, Aspenström P, Heldin C-H, Landström M (2005) Interaction between Smad7 and beta-catenin: importance for transforming growth factor beta-induced apoptosis. Mol Cell Biol. 25(4):1475-88. 